\title{
Herbal Medicines Targeting the Improved $\beta$-Cell Functions and $\beta$-Cell Regeneration for the Management of Diabetes Mellitus
}

\author{
Akurange Sujeevi Dammadinna Wickramasinghe $\mathbb{D D}^{1}$ Pabasara Kalansuriya ${ }^{1}{ }^{2}$ \\ and Anoja Priyadarshani Attanayake $\mathbb{D}^{2}$ \\ ${ }^{1}$ Department of Pharmacy, Faculty of Health Sciences, The Open University of Sri Lanka, Nawala, Sri Lanka \\ ${ }^{2}$ Department of Biochemistry, Faculty of Medicine, University of Ruhuna, Galle, Sri Lanka \\ Correspondence should be addressed to Anoja Priyadarshani Attanayake; anoja715@yahoo.com
}

Received 9 April 2021; Accepted 5 July 2021; Published 15 July 2021

Academic Editor: Guang Chen

Copyright (C) 2021 Akurange Sujeevi Dammadinna Wickramasinghe et al. This is an open access article distributed under the Creative Commons Attribution License, which permits unrestricted use, distribution, and reproduction in any medium, provided the original work is properly cited.

\begin{abstract}
There is an increasing trend of investigating natural bioactive compounds targeting pancreatic $\beta$-cells for the prevention/ treatment of diabetes mellitus (DM). With the exploration of multiple mechanisms by which $\beta$-cells involve in the pathogenesis of $\mathrm{DM}$, herbal medicines are gaining attention due to their multitasking ability as evidenced by traditional medicine practices. This review attempts to summarize herbal medicines with the potential for improvement of $\beta$-cell functions and regeneration as scientifically proven by in vivo/in vitro investigations. Furthermore, attempts have been made to identify the mechanisms of improving the function and regeneration of $\beta$-cells by herbal medicines. Relevant data published from January 2009 to March 2020 were collected by searching electronic databases "PubMed," "ScienceDirect," and "Google Scholar" and studied for this review. Single herbal extracts, polyherbal mixtures, and isolated compounds derived from approximately 110 medicinal plants belonging to 51 different plant families had been investigated in recent years and found to be targeting $\beta$-cells. Many herbal medicines showed improvement of $\beta$-cell function as observed through homeostatic model assessment- $\beta$-cell function (HOMA$\beta$ ). Pancreatic $\beta$-cell regeneration as observed in histopathological and immunohistochemical studies in terms of increase of size and number of functional $\beta$-cells was also prominent. Increasing $\beta$-cell mass via expression of genes/proteins related to antiapoptotic actions and $\beta$-cell neogenesis/proliferation, increasing glucose-stimulated insulin secretion via activating glucose transporter-2 (GLUT-2) receptors, and/or increasing intracellular $\mathrm{Ca}^{2+}$ levels were observed upon treatment of some herbal medicines. Some herbal medicines acted on various insulin signaling pathways. Furthermore, many herbal medicines showed protective effects on $\beta$-cells via reduction of oxidative stress and inflammation. However, there are many unexplored avenues. Thus, further investigations are warranted in elucidating mechanisms of improving $\beta$-cell function and mass by herbal medicines, their structure-activity relationship (SAR), and toxicities of these herbal medicines.
\end{abstract}

\section{Introduction}

DM is a chronic metabolic disorder characterized by hyperglycemia which is caused by deficiency of insulin secretion, insulin action, or both [1]. DM has become a major global health issue since it causes premature mortality and lower quality of life due to diabetes-related complications. According to the latest data provided by the International Diabetes Federation, the global adult population (20-79 years) with DM was approximately 463 million (9.3\% of the global adult population) in the year 2019 and is estimated to rise up to 700 million by the year 2045. DM and its complications caused 4.2 million deaths worldwide in the year 2019. The prevalence of DM among the Sri Lankan adult population is reported as $8.7 \%$ [2]. DM accounts for $9 \%$ mortality of all deaths in Sri Lanka [3]. The majority of DM cases can be categorized into two broad categories, i.e., type 1 diabetes mellitus (T1DM) and type 2 diabetes mellitus (T2DM). T1DM is caused due to autoimmune $\beta$-cell destruction which leads to an absolute deficiency of insulin secretion whereas T2DM resulted from a combination of resistance to insulin and inadequate compensatory insulin 
secretion [4]. At present, around 90\% of diabetic cases are of T2DM with the highest proportion in low and middle-income countries [2].

Pancreatic $\beta$-cells which secrete the anabolic hormone insulin have an important role in glucose homeostasis hence in the pathogenesis of DM [5]. Insulin is a polypeptide consisting of two chains of amino acids known as A and B chains, linked by three disulfide bridges. Initially, a peptide chain known as preproinsulin is synthesized by mRNA coded for insulin which gets converted to proinsulin in the endoplasmic reticulum. Proinsulin is then shifted to the Golgi apparatus and assembled into granules. The peptide segment connecting the $\mathrm{A}$ and $\mathrm{B}$ chains, the connecting peptide (C-peptide), is detached in the granules before insulin secretion making equimolar amounts of insulin and $\mathrm{C}$-peptide in the granules. C-peptide levels can be measured, and its level in the blood provides an index of $\beta$-cell function in patients receiving exogenous insulin [6].

An overview of mechanisms involved in $\beta$-cell damage and dysfunction in the pathogenesis of T1DM and T2DM is presented in Figure 1. Autoimmune destruction of islets of Langerhans/ $\beta$-cells leads to the development of T1DM. It has been found that human leukocyte antigen (HLA) encodes cell surface proteins of the islets that interact with immune cells. Activated cytotoxic CD8+ T lymphocytes via the aforementioned HLA genetic factor cause damage to $\beta$-cells. Furthermore, inflammatory stress caused by cytokines secreted by $\mathrm{T}$ lymphocytes also causes damage to $\beta$-cells. The presence of multiple autoantibodies can be seen in T1DM; however, their contribution to the pathogenesis of T1DM is not confirmed [7]. T2DM occurs due to insulin resistance associated with a defect of compensatory insulin secretion. Insulin resistance is multifactorial and commonly develops with obesity and aging. Genetic factors as well as lifestyle changes affect insulin resistance and then T2DM. Decreased muscle glucose uptake and impaired suppression of hepatic glucose production due to insulin resistance are the main causes of hyperglycemia observed in T2DM. Toxicity exerted by chronic exposure of the $\beta$-cell to glucose and fatty acids is believed to be leading to $\beta$-cell damage and dysfunction in T2DM subjects. Chronic hyperglycemia also leads to glycation reactions, and the production of reactive oxygen species causes $\beta$-cell damage in T2DM $[8,9]$.

The exact mechanisms of alteration of $\beta$-cell mass and function in the pathogenesis of DM are still unclear. However, it has been proven that $\beta$-cell mass and function begin to alter in both T1DM and T2DM even before the symptoms are shown. In T1DM, autoimmune destruction initially reduces $\beta$-cell mass, and exhaustion of remaining $\beta$-cells in compensating increased insulin requirement results in subsequent $\beta$-cell dysfunctions. In T2DM, initially, $\beta$-cell dysfunction occurs due to exhaustion of $\beta$-cells in compensating increased insulin requirement imposed by insulin resistance. This leads to a reduction of the $\beta$-cell mass due to cytotoxicity exerted by hyperglycemic conditions. Hence, in general, therapies targeted at increasing $\beta$-cell mass and therapies targeted at improving $\beta$-cell function could be considered as the main treatment and prevention targets of the disease for T1DM and T2DM, respectively [10].
Pancreatic $\beta$-cell mass and abnormalities of the structure can be assessed by histopathological examination or immunohistochemical analysis of the pancreatic tissue $[10,11]$. The histopathological examination involves morphometric analysis such as islet size and density, fractional $\beta$-cell area, and the number of apoptotic $\beta$-cells. Immunohistochemical staining using anti-insulin antibodies is important in the assessment of functional $\beta$-cell mass whereas anti-Ki67 antibodies are used in the assessment of $\beta$-cell proliferation [12]. Homeostatic model assessment- $\beta$-cell function (HOMA- $\beta$ ) is a mathematical model used for the estimation of $\beta$-cell function from measurements of fasting plasma glucose and insulin or C-peptide. HOMA- $\beta$ is calculated using the fasting plasma glucose, and insulin hence can be used to evaluate $\beta$-cell function in the fasting state. For detailed investigation of defects of $\beta$-cell, dynamic tests such as intravenous glucose, arginine, or glucagon are also used in combination with a hyperglycemic clamp. The $\beta$-cell function during daily-life conditions is evaluated using an oral glucose tolerance test (OGTT) or a mixed meal tolerance test in combination with an estimation of insulin secretion rates and mathematical modeling [13]. Assessment of gene expressions and protein profiling is also used in assessing $\beta$-cell regeneration and function. None of the aforementioned methods on its own is considered the gold standard for assessing $\beta$-cell function. Hence, a combination of several methods is needed for a better conclusion [13].

$\beta$-Cell regeneration can occur via replication of existing $\beta$-cell or conversion of other pancreatic cells into $\beta$-cells. Examples for investigations on experimental drugs derived from the natural origin for their ability to improve $\beta$-cell regeneration are summarized in Table 1 . $\beta$-Cell replication is mediated by the inhibition of multiple mitogenic signaling pathways. Experimental drugs such as harmine and aminopyrazine compounds have shown $\beta$-cell regenerative potential in this manner $[14,15]$. Modification of distinct genes which are associated with the development of $\beta$-cell during embryogenesis has a prominent role in converting other cells in the pancreas to $\beta$-cells. Drugs such as $\gamma$-aminobutyric acid and artemether act as potential activators of conversion of other cells to $\beta$-cells $[16,17]$. Furthermore, there is a possibility of generating $\beta$-cells from progenitor cells, including human embryonic and induced pluripotent stem cells derived from somatic cell populations [18].

A $\beta$-cell function can be restored by stimulating insulin secretory pathways. Sulfonylureas (e.g., glimepiride and glipizide) are believed to stimulate insulin release through activating the $\mathrm{K}^{+} / \mathrm{ATP} /$ sulfonylurea receptor channels. Though these drugs initially reduce hyperglycemia, eventually $\beta$-cells may get damaged due to exhaustion. Incretin peptides amplify insulin release in a glucose-dependent manner. Glucagon-like peptide 1 (GLP-1) receptor agonists (e.g., polypeptide compounds: liraglutide, exenatide) are effective in promoting biphasic insulin release and rarely cause hypoglycemia or body weight gain. Dipeptidyl peptidase 4 (DPP-4) inhibitors (e.g., vildagliptin and sitagliptin) also contributed to improving $\beta$-cell function by prolonging the half-life of incretins via prevention of their rapid 
degradation. It has been suggested that promoting insulin sensitization is a better approach for glycemic control rather than increasing insulin secretion alone which may cause exhaustion of $\beta$-cells [19].

Available allopathic drugs have not been able to restore $\beta$-cell function or regeneration and are also associated with side effects such as weight gain, weight loss, hypoglycemia, and abdominal discomforts [20]. Apart from the lifestyle interventions, stem cell treatments and pancreatic islet transplants are also utilized for the management of DM but none has been able to totally manage the disease. Hence, medicinal plants with a history of use in traditional medicine practices and as evident by ethnopharmacological knowledge have gained attention to be used as antidiabetic therapeutics to restore $\beta$-cell functions and mass due to their multitasking ability as in targeting different aspects of the pathways in $\beta$-cell regeneration and function [21]. There are limited reviews on these natural products targeting $\beta$-cells. Oh and Semwal et al. provided comprehensive details on investigations conducted on plant-derived natural products targeting $\beta$-cells $[22,23]$. However, they lack the emphasis on cellular and molecular mechanisms of restoring $\beta$-cell function and $\beta$-cell mass, their structure-activity relationships, and toxicity concerns. Ghorbani et al. discussed the cellular and molecular mechanisms of restoring $\beta$-cell function and $\beta$-cell mass but the focus was confined to flavonoids [24]. This review attempts to identify the mentioned aspects and elaborate unexplored avenues for future research. We believe that with the given information it would be possible to fill the gap between existing knowledge and unexplored avenues in herbal medicines targeting $\beta$-cells.

\section{Description of Study Selection}

Online electronic databases "PubMed," "ScienceDirect," and "Google Scholar" were searched with the keywords "medicinal plant extracts," "phytoconstituent," " $\beta$-cell regeneration," " $\beta$-cell function," and "diabetes mellitus" in the whole text. A combination of these keywords with relevant Boolean operators was used in searching. Data were collected from January 2009 to March 2020. Studies on the effects of plant crude extracts/fractions/isolated compounds on $\beta$-cell structure and function using in vitro cell culture studies and/or in vivo models of T1DM and T2DM were selected for this review. Studies on commercial oral hypoglycemic agents other than plant-derived drugs and synthetic drugs with natural product moiety were excluded. Studies with no direct evidence on $\beta$-cell function and mass but indirectly suggested improvement of those activities via improving insulin resistance and other antidiabetic parameters were also excluded. Accordingly, in the PubMed database, a total of 81 hits were obtained. Out of them, 39 articles were excluded being not relevant to the scope of this review. The remaining 42 articles were selected for the study. In the ScienceDirect database, under the category of research articles, a total of 753 hits were obtained and 24,100 hits were obtained via Google Scholar. First, the most relevant 100 articles were selected from each database, i.e., ScienceDirect and Google Scholar. Out of 100, 58 articles in ScienceDirect were excluded for being not within the scope, and four articles were excluded being duplications. The remaining 38 articles were selected for the review. Out of 100 articles in Google Scholar, 64 articles were excluded for being not within the scope and seven articles were excluded being duplications. The remaining 29 articles were selected for the review. A total of 109 articles were studied for the review. A summary of the study selection process is shown in Figure 2.

\section{Results}

Plant-derived natural products, i.e., crude plant extracts, fractions, and isolated compounds, have been investigated for antidiabetic activity and are described in the following sections. Among these, some are reported as having potential for improving $\beta$-cell regeneration and function as evidenced by in vitro cell culture studies and animal and human studies. However, only a few natural products have been investigated for detailed mechanisms on regeneration and function of $\beta$-cell in the above models. In vitro cellular models and animal models have been applied widely in elucidating these mechanisms. In many instances, polyphenol compounds including flavonoids that possess pronounced antioxidant activities were found to be improving $\beta$-cell regeneration and function.

3.1. Single Herbal Extracts Targeting $\beta$-Cells. Extracts of Artemisia dracunculus L. (Family: Compositae), Centaurium erythraea Rafn (Family: Gentianaceae), Cornus officinalis Sieb. et Zucc. (Family: Cornaceae), Gynura divaricata (L.) DC (Family: Asteraceae), Hibiscus rosa sinensis Linn. (Family: Malvaceae), Lactarius deterrimus (Family: Russulaceae), Myrica rubra Sieb. and Zucc. (Family: Myricaceae), Panax ginseng C.A. Meyer (Family: Araliaceae), Tamarindus indica Linn. (Family: Fabaceae), Teucrium polium L. (Family: Lamiaceae), Thymus praecox subsp. skorpilii var. skorpilii (Family: Lamiaceae), Uncaria tomentosa (Willd.) DC (Family: Rubiaceae), and Woodfordia fruticosa (L.) Kurz (Family: Lythraceae) have shown improvement of $\beta$-cell regeneration and function through different mechanisms. The following sections are focused on the investigations conducted on herbal medicines with the potential for improving regeneration and function of $\beta$-cell.

3.1.1. Artemisia dracunculus L. Ethanol ( $80 \% \mathrm{v} / \mathrm{v})$ extract of seeds of Artemisia dracunculus was investigated in vitro using islets of Langerhans isolated from mouse, NIT-1 cells (a pancreatic $\beta$-cell line established from a transgenic NOD/ Lt mouse), and human islets. Mouse islets and NIT-1 cells were exposed to $1 \mathrm{mM}$ glucose, and human islets were exposed to $2.8 \mathrm{mM}$ glucose prior to treatment with the extract. A significant $(p<0.05)$ increase in glucose-stimulated insulin release was observed in the aforementioned cells when treated with $10 \mu \mathrm{g} / \mathrm{mL}$ of the extract. MTT $((3-(4,5-\mathrm{di}-$ methylthiazol-2-yl)-2, 5-diphenyltetrazolium bromide)) assay revealed that the extracts are not cytotoxic at tested concentrations. Furthermore, it was revealed that extracts do 
not increase $\beta$-cell mass in any of the concentrations. Western blot analysis of protein extract of NIT-1 cells treated with plant extract showed activation of the AMPactivated protein kinase (AMPK) followed by acetyl-CoA carboxylate (ACC) and protein kinase $\mathrm{B}$ ( $\mathrm{PKB} / \mathrm{Akt}$ ) which was suggested as a possible mechanism for glucose-stimulated insulin secretion [25]. However, the AMPK activity on $\beta$-cell function and mass is still under debate, and controversial findings are reported among studies conducted to date. There is growing evidence toward the concept that AMPK activation in $\beta$-cells may cause decreased insulin secretion $[26,27]$. There are contradictory theories on the effect of activation of AMPK on $\beta$-cell apoptosis/survival. However, the activation of Akt has been found to inhibit the AMPK-activated apoptosis of $\beta$-cells [28]. Hence, the suggested mechanism should be further investigated to ascertain the mechanism of increasing glucose-stimulated insulin secretion and survival of $\beta$-cells by the investigated plant extract.

3.1.2. Centaurium erythraea Rafn. Centaurium erythraea is a traditional medicinal plant in Serbia used to treat DM. Methanolic extract of dried aerial parts of C. erythraea has been investigated for its mechanisms of improving $\beta$-cell regeneration and function. In vivo studies were carried out using male albino Wistar rats weighing 220-250 g with DM induced by multiple intraperitoneal (i.p.) injections of a low dose of streptozotocin (STZ) $(40 \mathrm{mg} / \mathrm{kg})$. Oral administration of the extract at a dose of $100 \mathrm{mg} / \mathrm{kg}$ for four weeks resulted in significant improvement of glycemic control as evidenced by significant $(p<0.01)$ reduction of blood glucose level (33\%) and increased insulin level (74\%) in diabetic rats. Furthermore, hematoxylin and eosin (H\&E) stained pancreatic sections showed that the shape, size, and number of islets and the number of $\beta$-cells returned back to normal upon treatment. Immunohistochemical staining of the pancreatic tissue with anti-insulin antibodies showed an increase in the number and distribution of $\beta$-cells.

Staining of pancreatic islets for GLUT-2 has shown positive GLUT-2 staining with a uniform distribution of GLUT-2 within the islets. The GLUT-2 is responsible for glucose entry into $\beta$-cells and thereby stimulating insulin synthesis. Immunohistochemical analysis of the pancreatic tissue of diabetic rats revealed the presence of activated protein kinase B ( $\mathrm{p}$-Akt) uniformly distributed throughout the islets. Akt plays an important role in the regulation of pancreatic $\beta$-cell growth and survival [29]. It has been found that overexpression and activation of Akt in $\beta$-cells result in an increase in the $\beta$-cell mass, cell size, and proliferation [30].

Further studies on pancreatic islet tumor Rin-5F cells revealed that cells induced with $12 \mathrm{mM}$ STZ have a significant increase of $12 \%$ in cell viability in the presence of $0.25 \mathrm{mg} / \mathrm{mL}$ of extract. Furthermore, treatment with the extract showed a $77 \%$ increase in insulin 1 (Ins1) gene (i.e., the gene encoding insulin) expression and a $90 \%$ increase in insulin secretion and protection of DNA from damage.
Treatment with the extract also exhibited an antioxidant effect on $\beta$-cells in terms of reduction of lipid peroxidation [malondialdehyde (MDA) level (27\%), protein S-glutathionylation (GSSP) (40\%)] and increased ratio of reduced glutathione/oxidized glutathione (GSH/GSSG) (8\%). Amelioration of STZ-induced oxidative stress was evident by decreased activity of antioxidant enzymes including manganese superoxide dismutase (MnSOD) (22\%), copper-zinc superoxide dismutase (CuZnSOD) (11\%), and catalase (CAT) (to a normal level). Furthermore, it was observed that STZ-induced oxidative stress caused imbalances in activities of redox-sensitive transcription factors, nuclear factor- $\kappa \mathrm{B}-\mathrm{p}$ 65 subunit (NF- $\kappa \mathrm{B}-\mathrm{p} 65)$, nuclear factor erythroid 2-related factor 2 (Nrf-2), and specificity protein 1 (Sp1) which are involved in the transcriptional regulation of aforementioned antioxidant enzymes. Treatment with the extract resulted in the readjustment of these factors by reducing NF- $\kappa \mathrm{B}-\mathrm{p}-65$ (24\%) and Nrf-2 (3-fold) and increasing Sp1 (to a normal level) [29]. Furthermore, it was revealed that the extract contains secoiridoids (secologanin, sweroside, swertiamarin, gentiopicrin, and loganin) and polyphenols including phenolic acids (sinapic acid, caffeic acid, ferulic acid, and $p$ coumaric acid), flavonoids, i.e., flavones (apigenin and luteolin), flavonols (rutin, isoquercitrin, astragalin, kaempferol, quercetin), flavanones (naringenin), and xanthones (eustomin, desmethyleustomin, methylbellidifolin, and decussatin) [31].

3.1.3. Cornus officinalis Sieb. et Zucc. Aqueous extract of dried fruits of Cornus officinalis at a dose of $500 \mu \mathrm{g} / \mathrm{mL}$ was investigated in a T1DM model using human 1.1B4 pancreatic $\beta$-cells. The extract accelerated $\beta$-cell regeneration following cytokine-induced death. Furthermore, the treatment showed a 2 -fold increase in cell proliferation. The plant extract was found to be rich in iridoid glycosides. It was suggested that the effects might be due to the observed twofold increase in the gene expression of the calciumdependent transcription factor, nuclear factor of activated T cells, and cytoplasmic 2 (NFATC2) [32]. NFATC2 is considered the key transcriptional factor which regulates transcription of many genes associated with DM thereby promoting $\beta$-cell proliferation and function [33].

3.1.4. Gynura divaricata (L.) DC. Gynura divaricata is a traditional Chinese medicinal herb with antidiabetic activity. Methanolic extract of aerial parts of $G$. divaricata has been investigated in ICR mice (three weeks of age) with T2DM induced by a high-fat diet followed by i.p. injection of STZ $(100 \mathrm{mg} / \mathrm{kg})$. It was found that the crude extract contains polyphenolic compounds including 3caffeoylquinic acid, 4,5-dicaffeoylquinic acid, 3,4-dicaffeoylquinic acid, and 3,5-dicaffeoylquinic acid. The incorporation of $10 \% \mathrm{G}$. divaricata to the diet of the diabetic mice for four weeks caused a marked recovery of pancreatic islets with an increase of $\beta$-cell counts, and an improvement of islet structure which was observed on $\mathrm{H} \& \mathrm{E}$ staining. An immunohistochemical study using anti-insulin antibodies showed an increased number of 


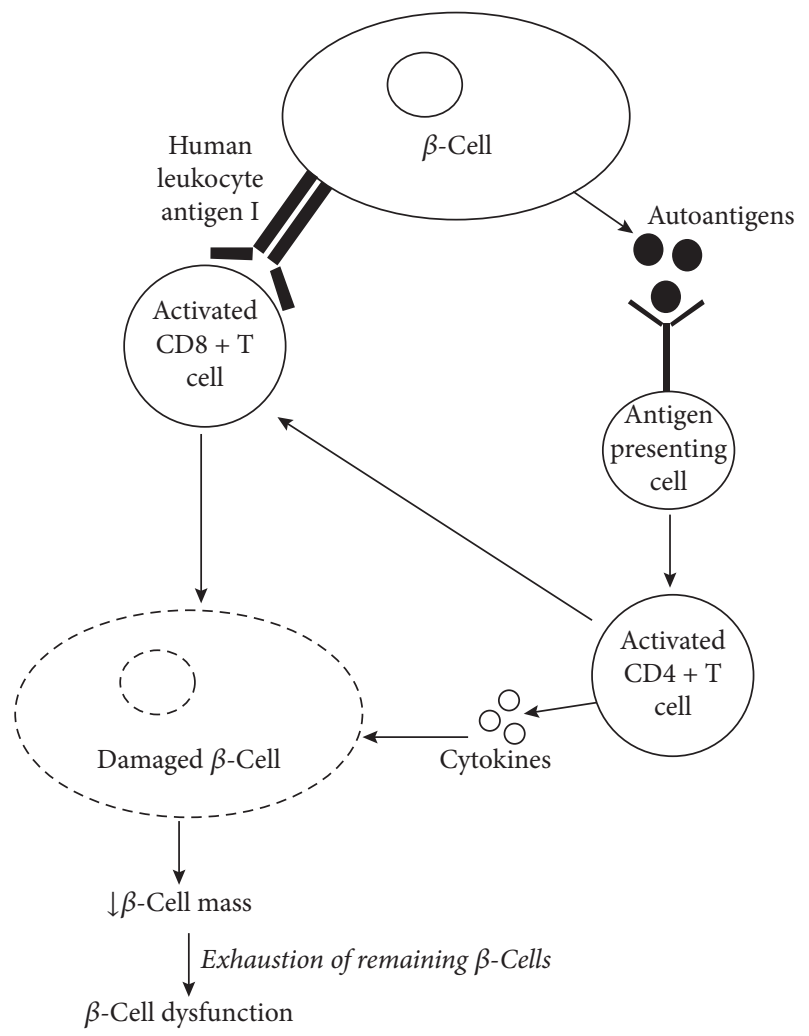

(a)

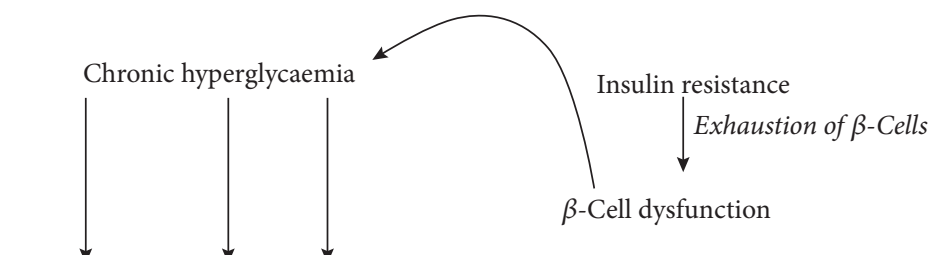

$\uparrow$ Glucose $\uparrow$ Fatty acids $\uparrow$ Reactive oxygen species

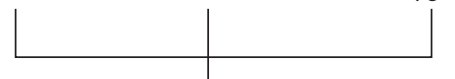

(b)

Figure 1: An overview of mechanisms involved in $\beta$-cell damage and dysfunction in (a) type 1 diabetes mellitus and (b) type 2 diabetes mellitus.

TABLE 1: Investigations on experimental drugs derived from plant sources for their ability to improve $\beta$-cell regeneration.

\begin{tabular}{|c|c|c|c|c|}
\hline $\begin{array}{l}\text { Experimental } \\
\text { drug }\end{array}$ & Experimental system & Dose & $\beta$-Cell regeneration mechanism & Reference \\
\hline \multirow{2}{*}{ Harmine } & $\begin{array}{l}\text { C57B6 mice with partial pancreatectomy and } \\
\text { human islet transplantation }\end{array}$ & $\begin{array}{l}10 \mathrm{mg} / \\
\mathrm{kg}\end{array}$ & $\beta$-Cell proliferation & \multirow[t]{2}{*}[14]{} \\
\hline & $\begin{array}{l}\text { Rat insulinoma (Ins1 823/13) and human hepatoma } \\
\text { (HepG2) cell lines }\end{array}$ & $1-15 \mu \mathrm{M}$ & $\beta$-Cell proliferation & \\
\hline $\begin{array}{l}\gamma \text {-Aminobutyric } \\
\text { acid }\end{array}$ & $\begin{array}{l}\text { Wild-type transgenic mice induced with } \\
\text { streptozotocin }(60 \mathrm{mg} / \mathrm{kg})\end{array}$ & $\begin{array}{l}250 \mu \mathrm{g} / \\
\mathrm{kg}\end{array}$ & $\begin{array}{c}\beta \text {-Cell regeneration via differentiation of } \\
\alpha \text {-cells to } \beta \text {-cells }\end{array}$ & {$[16]$} \\
\hline \multirow{3}{*}{ Artemether } & $\begin{array}{l}\text { Mouse } \beta \text {-cell line (Min6) induced with doxycycline } \\
(1 \mu \mathrm{g} / \mathrm{mL}) \text { for overexpression of ARX transcription } \\
\text { factor }\end{array}$ & $10 \mu \mathrm{M}$ & $\begin{array}{c}\text { ARX repression thereby increase } \beta \text {-cell } \\
\text { turnover and conversion of } \alpha \text {-cells to } \\
\beta \text {-cells }\end{array}$ & \multirow[t]{3}{*}[17]{} \\
\hline & $\begin{array}{l}\text { Zebrafish larvae induced with dimerizer AP20187 } \\
\qquad(2 \mu \mathrm{M})\end{array}$ & $5 \mu \mathrm{M}$ & $\begin{array}{c}\beta \text {-Cell proliferation and conversion of } \\
\alpha \text {-cells to } \beta \text {-cells }\end{array}$ & \\
\hline & $\begin{array}{l}\text { Sprague-Dawley rats induced with streptozotocin } \\
\qquad(60 \mathrm{mg} / \mathrm{kg})\end{array}$ & $\begin{array}{l}20-200 \\
\mathrm{mg} / \mathrm{kg}\end{array}$ & $\begin{array}{c}\beta \text {-Cell proliferation and conversion of } \\
\alpha \text {-cells to } \beta \text {-cells }\end{array}$ & \\
\hline
\end{tabular}

insulin-positive $\beta$-cells reflecting $\beta$-cell regeneration. A significant $(p<0.01)$ increase in the expression of GLUT2, glucokinase (GK), v-maf musculoaponeurotic fibrosarcoma oncogene family protein A (MafA), and pancreatic duodenal homeobox-1 (PDX-1) was observed reflecting increased functioning of pancreatic $\beta$-cells. PDX-1 and MafA are important transcription factors which regulate gene expressions in $\beta$-cells. PDX-1 is essential for the development of pancreatic cells including $\beta$-cells and involves insulin gene transcription. MafA binds to the promoter region of the insulin gene promoting insulin expression in response to glucose [34]. An increase in the expression of antiapoptotic protein and B-cell lymphoma-2 (Bcl-2) and a decrease in the expression of apoptotic proteins, Bcl2associated $\mathrm{X}(\mathrm{Bax})$, and cysteinyl aspartate specific proteinase-3 (caspase-3) suggesting $\beta$-cell survival were also observed. Accordingly, G. divaricata crude extract showed pronounced hypoglycemic effects by inhibiting islet cell apoptosis and improving pancreatic function [35]. 
3.1.5. Hibiscus rosa sinensis Linn. Hibiscus rosa sinensis is an Ayurvedic medicinal plant used in India for the treatment of DM. Aqueous extract of flower petals of $H$. rosa sinensis was investigated in glucose-stressed RIN-m5F cells. Cells treated with $50 \mu \mathrm{g} / \mathrm{mL}$ extract elevated the release of insulin and modulated apoptotic signaling pathways in $\beta$-cells. It significantly $(p<0.05)$ reduced $\mathrm{NF}-\kappa \mathrm{B}$ nuclear translocation, thereby downregulated the expressions of major inflammatory cytokines, and upregulated expressions of pancreatic $\beta$-cell functional genes, i.e., forkhead box O1 (FOXO-1), Urocortin 3 (Ucn-3), PDX-1, MafA, and natural killer cell transcription factor-related, gene family 6, locus 1 (Nkx6.1) suggesting its protective effects on $\beta$-cells. Major constituents of the extract responsible for these activities are supposed to be polyphenols including myricetin (1), syringic acid (2), and ferulic acid (3) (Figure 3) [36].

3.1.6. Lactarius deterrimus. Ethanol (50\% v/v) extract of dried mushroom Lactarius deterrimus was investigated in 2.5- month-old adult albino Wistar rats weighing 220-250 g with DM induced by multiple low dose STZ (40 mg/kg/day) i.p. injection. Intraperitoneal administration of the extract $(60 \mathrm{mg} / \mathrm{kg})$ daily for four weeks increased the expression of chemokine CXCL12 protein. CXCL12 protein is involved in the activation of the serine/threoninespecific Akt prosurvival pathway causing restoration of $\beta$-cell population. $\beta$-Cell regeneration was further emphasized by an increase in the numbers of proliferating cell nuclear antigen (PCNA), i.e., an intranuclear polypeptide expressed during cell proliferation, and insulinpositive $\beta$-cells. These results indicated the potential of the $L$. deterrimus extract to alleviate oxidative stress and increase $\beta$-cell mass [37].

3.1.7. Myrica rubra Sieb. and Zucc. Myrica rubra (bayberry) fruit extract rich in cyanidin-3-glucoside (4) (Figure 3) was investigated in vitro using pancreatic $\beta$-cells and in vivo using mice induced with DM by i.p. injection of STZ $(200 \mathrm{mg} / \mathrm{kg})$. Pretreatment of $\beta$-cells exposed to hydrogen peroxide $\left(\mathrm{H}_{2} \mathrm{O}_{2}\right)$ with the extract at a dose of $15 \mu \mathrm{g} / \mathrm{g}$ resulted in increased cellular viability and decreased mitochondrial reactive oxygen species production and prevented cell death and cell necrosis. Furthermore, the extract upregulated PDX-1 gene expression, contributing to increased gene transcription of insulin-like growth factor 2 (IGF-2) and insulin in INS-1 cells (rat insulinoma cell line, a $\beta$-cell line) [38].

3.1.8. Panax ginseng C.A. Meyer. Butanol extract of Panax ginseng was investigated in mice with DM induced by i.p. injection of STZ at a dose of $80 \mathrm{mg} / \mathrm{kg}$ and INS-1 cells. The oral administration of the extract $(200 \mathrm{mg} / \mathrm{kg})$ for diabetic rats for 10 weeks resulted in enhanced glucose-stimulated insulin secretion and $\beta$-cell proliferation. Incubation of INS1 cells with the extract for 24 hours resulted in an increase in the number of $\beta$-cells. Furthermore, the treatment of INS-1 cells with the extract $(5 \mu \mathrm{g} / \mathrm{mL})$ increased the gene expressions of cyclin D2, PDX-1, and insulin receptor substrate 2 (IRS-2) which were suggested as the mechanism of $\beta$-cell proliferation. Ginsenosides (steroid glycosides) present in the extract would be causing the observed biological effects [39].

3.1.9. Tamarindus indica Linn. Aqueous extract of seeds of Tamarindus indica was investigated in rats induced with DM by i.p. injection of STZ ( $90 \mathrm{mg} / \mathrm{kg})$. Oral administration of $240 \mathrm{mg} / \mathrm{kg}$ extract for four weeks resulted in a slight decrease in the number of insulin-positive granules compared to the control group. Furthermore, islet atrophy was not detected compared to the control group indicating protective effects against $\beta$-cell damage. The anti-inflammatory activity of the extract was represented by a significant $(p<0.05)$ reduction of tumor necrosis factor- $\alpha$ (TNF- $\alpha$ ) level. An increased insulin secretion via increasing $(p<0.001)$ cytosolic $\mathrm{Ca}^{2+}$ levels was observed in islets isolated from rats upon treatment with $100 \mu \mathrm{g} / \mathrm{mL}$ extract [40].

3.1.10. Teucrium polium L. Hydroalcoholic extract of aerial parts of Teucrium polium was investigated for its antidiabetic activity in rats induced with DM by single i.p. injection of STZ $(45 \mathrm{mg} / \mathrm{kg})$. The administration of $0.5 \mathrm{~g} / \mathrm{kg}$ extract to diabetic rats for 42 days resulted in increased $\beta$-cell mass. Treatment with $T$. polium extract also caused a reduction in the MDA (64\%) level and increment of the pancreatic superoxide dismutase (SOD) (EC 1.15.1.1) (45\%), CAT (EC 1.11.1.6) (52\%), and GSH (105\%) contents indicating amelioration of oxidative stress. Assessment of transcription factors showed higher levels of PDX-1 in diabetic rats while the level of FOXO-1 decreased. c-Jun N-terminal kinase (JNK) activation under oxidative stress, which leads to FOXO-1 formation, is a molecular mechanism related to the destruction of $\beta$-cells. Nuclear accumulation of FOXO- 1 is believed to reduce the PDX-1 expression thereby reducing insulin gene expression. PDX-1 is also important in the restoration and proper function of the insulin-producing $\beta$-cells [41].

3.1.11. Thymus praecox subsp. skorpilii var. skorpilii. Thymus praecox is consumed as a decoction in Turkish folk medicine for the treatment of diabetes. Methanolic extract of aerial parts of this plant was investigated on STZ (55 mg/kg)/nicotinamide (NA) (100 mg/kg)-induced type 2 diabetic rats. Oral administration of the plant extract at a dose of $100 \mathrm{mg} / \mathrm{kg}$ for three weeks resulted in significant $(p<0.01)$ reduction of the proinflammatory cytokines (TNF- $\alpha$, interleukin-1 $\beta$-(IL-1 $\beta$ ), interleukin-6 (IL-6)), and significant $(p<0.001)$ elevation of glucagon-like peptide-1 (GLP-1) in the pancreas. Histopathological assessment of the pancreas showed protection of $\beta$-cells from STZ/NA-induced damage [42].

3.1.12. Uncaria tomentosa (Willd.) DC. Uncaria tomentosa is a native species to the Amazon rain forest and is widely used as traditional medicine for DM. Ethanol (50\% v/v) 


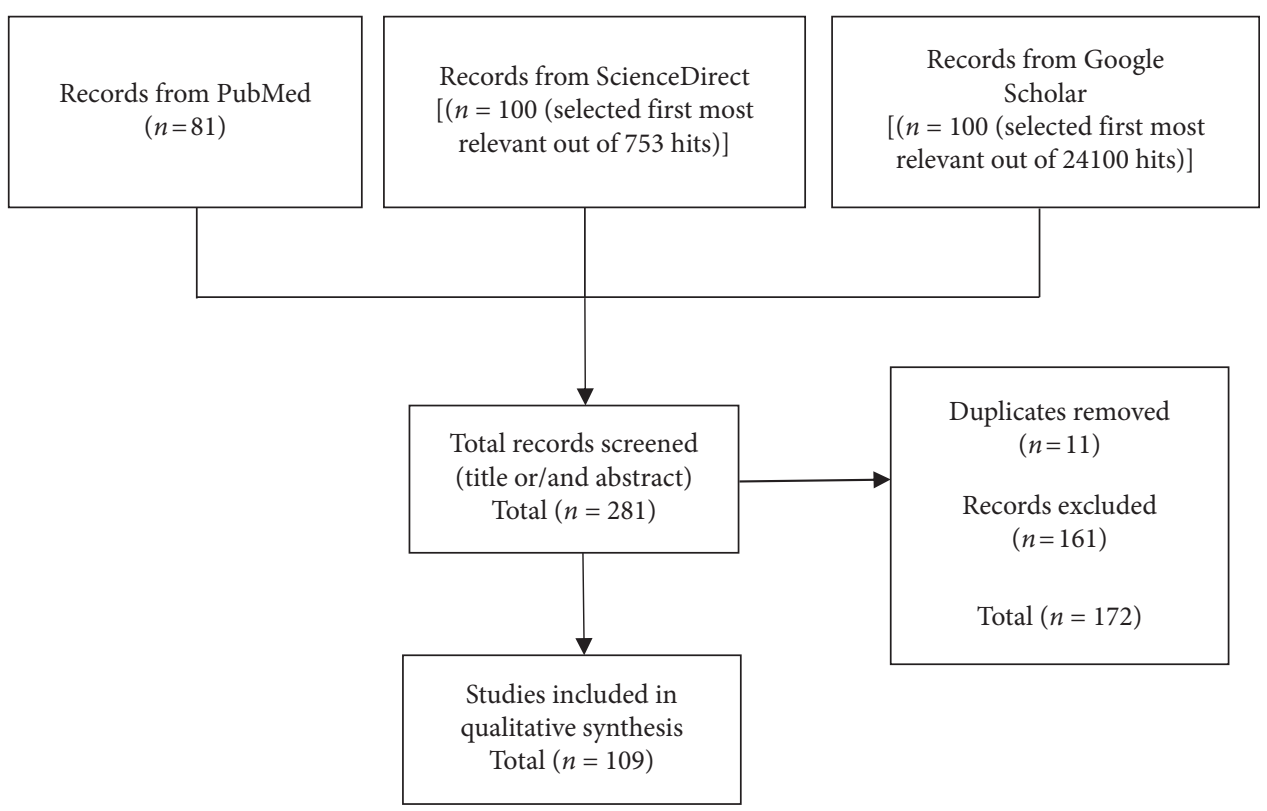

FIgURE 2: Study selection process.

extract of stem bark of $U$. tomentosa was investigated in sixweek-old C57BL/6 male mice with DM induced by five i.p. injections of STZ $(40 \mathrm{mg} / \mathrm{kg})$. Oral administration of $U$. tomentosa extract $(400 \mathrm{mg} / \mathrm{kg})$ for 21 days showed a higher number of intact islets and a significant inhibition of destructive insulitis in histopathological examination of the pancreatic tissue. Furthermore, the immunohistochemical evaluation showed an increase of insulin-positive $\beta$-cells. The phenotypic analysis indicated that treatment with higher doses $(100-400 \mathrm{mg} / \mathrm{kg}$ ) resulted in $\mathrm{CD} 4(+)$ and $\mathrm{CD} 8(+)$ $\mathrm{T}$-cell values similar to healthy animals. Same doses also increased the number of CD4(+), CD25(+), and Foxp3(+) regulatory $\mathrm{T}$ cells. Furthermore, the extract modulated the production of Th1 and Th2, with increased levels of IL-4 and IL-5. Altogether, results suggest the immunomodulatory action of extract and protection of $\beta$-cells from immune reactions.

Pentacyclic oxindole alkaloids, i.e., speciophylline (5), mitraphylline (6), uncarine F (7), pteropodine (8), isomitraphylline (9), and iso-pteropodine (10) (Figure 4), present in the extract exert the reported therapeutic activities [43].

3.1.13. Woodfordia fruticosa (L.) Kurz. Methanolic extract of flowers of Woodfordia fruticosa was investigated in Sprague-Dawley rats with diabetes induced by STZ (45 mg/kg)nicotinamide $(120 \mathrm{mg} / \mathrm{kg})$ i.p. injection. Treatment of diabetic rats with extract $(200 \mathrm{mg} / \mathrm{kg})$ for 45 days ameliorates oxidative stress by significantly $(p<0.05)$ downregulating lipid peroxidation levels. Furthermore, the histopathological analysis showed recovery in the structural degeneration of $\beta$-cell mass. The immunohistochemical study showed upregulation in insulin. Western blot analysis showed a slight increase in the GLUT-2 protein expression in the pancreas [44].

\subsection{Compounds Isolated from Plants Targeting $\beta$-Cells}

3.2.1. Salidroside. Salidroside (11) (Figure 5) is a phenylethanoid glycoside extracted from the medicinal plant Rhodiola rosea L. (Family: Crassulaceae). This compound was investigated in four-week-old male C57BL/6 mice fed with a high-fat diet. Oral administration of salidroside $(100 \mathrm{mg} / \mathrm{kg} /$ day $)$ for five weeks increased $\beta$-cell mass and $\beta$-cell replication of diabetic mice. The effects of salidroside under diabetic stimuli (glucose/cytokines) were further investigated in Min6 cells (a pancreatic $\beta$-cell line). Under diabetic stimuli, salidroside suppressed reactive oxygen species production and restored mitochondrial membrane potential via reducing NADPH oxidase 2 (NOX2) expression and inhibiting JNK-caspase 3 apoptotic cascade subsequently leading to $\beta$-cell survival. Simultaneously, it reversed diabetes-associated oxidative stress by activating AMPK-Akt to inhibit FOXO1 and recovering PDX-1 nuclear localization. Results indicated that salidroside prevents $\beta$-cell failure via AMPK activation [45].

3.2.2. Ginseng Oligopeptides. Panax ginseng Meyer (Family: Araliaceae) is a traditional Chinese medicinal herb used to treat DM. Administration of ginseng oligopeptides $(0.5 \mathrm{~g} / \mathrm{kg})$ for 52 days to Sprague-Dawley rats ( 5 weeks old, 130-170 g) with DM induced by high carbohydrate/high-fat diet followed by alloxan $(105 \mathrm{mg} / \mathrm{kg})$ injection resulted in an increase $(p<0.05)$ in the HOMA- $\beta$ values. The increase in insulin level and the decrease in expression of $\mathrm{NF}-\kappa \mathrm{B}$ and $\mathrm{Bcl}-2$ family in pancreatic islets were also detected by Western blot analysis. Histopathological examination of the pancreas of treated animals showed amelioration of pancreatic damage. Furthermore, the $\beta$-cell survival time and rate were significantly longer in treated animals [46]. 
<smiles>O=c1c(O)c(-c2cc(O)c(O)c(O)c2)oc2cc(O)cc(O)c12</smiles>

(a)<smiles>COc1cc(C(=O)O)cc(OC)c1O</smiles><smiles>COc1cc(/C=C/C(=O)O)ccc1O</smiles>

(c)<smiles>OC[C@H]1C[C@H](Oc2cc3c(O)cc(O)cc3[o+]c2-c2ccc(O)c(O)c2)[C@H](O)[C@@H](O)[C@H]1O</smiles>

(d)

Figure 3: Structures of metabolites: (a) myricetin (1), (b) syringic acid (2), (c) ferulic acid (3) present in Hibiscus rosa sinensis Linn., and (d) cyanidin-3-glucoside (4) present in Myrica rubra Sieb. and Zucc. targeting $\beta$-cells.

3.2.3. Puerarin. Puerarin (12) (Figure 5), an isoflavone from the root of Pueraria lobata (Willd.) Ohwi. (Family: Fabaceae), was investigated in vivo for its $\beta$-cell regeneration potential via glucagon-like peptide 1 receptor (GLP-1R) signaling activation. Oral administration of puerarin $(150 \mathrm{mg} / \mathrm{kg})$ daily for 10 days to $\mathrm{C} 57 \mathrm{BL} / 6$ diabetic mice fed with a high-fat diet increased the HOMA- $\beta$ and $\beta$-cell proliferation in pancreatic sections. The expression of transcription factors PDX-1 and neurogenin 3 (Ngn3) and upregulation of GLP-1R signaling in isolated pancreatic ductal epithelial cells indicated $\beta$-cell neogenesis. Small islet-like cell clusters (ICCs) were observed indicating ductal epithelium differentiation. Efficacy of puerarin was suppressed in vivo by GLP-1R antagonist exendin-9-39 but was enhanced by exendin-4, a GLP-1R agonist indicating the effect of puerarin in GLP-1R activation [47].

3.2.4. Vitexin. Vitexin (13) (Figure 5) is a C-glycosyl flavonoid isolated from leaves of Ficus deltoidea Jack (Family: Moraceae). INS-1 cells pretreated with vitexin (20 and
$40 \mu \mathrm{M})$ followed by exposure to high glucose $(33 \mathrm{mM})$ were protected against cytotoxicity exert by high glucose concentration. Vitexin improved insulin signaling as analyzed by the levels of functional proteins including GLUT-2, insulin receptor (IR), IRS-1, and IRS-2 and causing glucosestimulated insulin secretion. Vitexin improved the high glucose-induced nuclear transcription factor system by suppressing Rel A, Rel B, I $\mathrm{B}$, and P50/p105 expression resulting in decreased cell apoptosis, further confirmed by the reduction in the percentage of Annexin-V (i.e., a fluorescent stain for detect apoptotic cells) positive cells. Furthermore, vitexin activated proteins including NF- $\kappa \mathrm{B}$ and $\mathrm{Nrf} 2$ in $\beta$-cells regulating apoptosis [48].

3.2.5. Saponins. Saponins isolated from Momordica charantia L. (Family: Cucurbitaceae) on insulin secretion were investigated on INS-1 pancreatic $\beta$-cells exposed to high glucose concentration $(33.3 \mathrm{mM})$. Treating these cells with saponins caused improved cell morphology and increased 


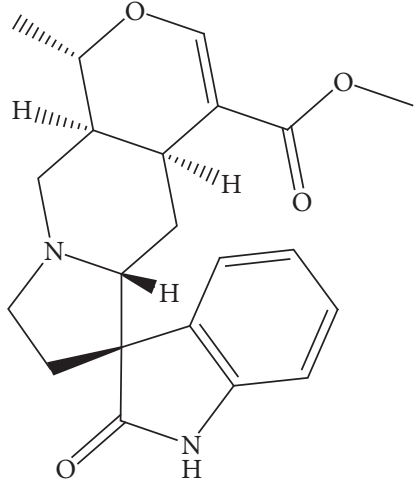

(a)

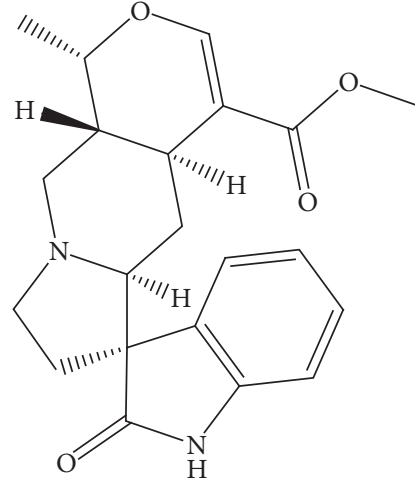

(b)

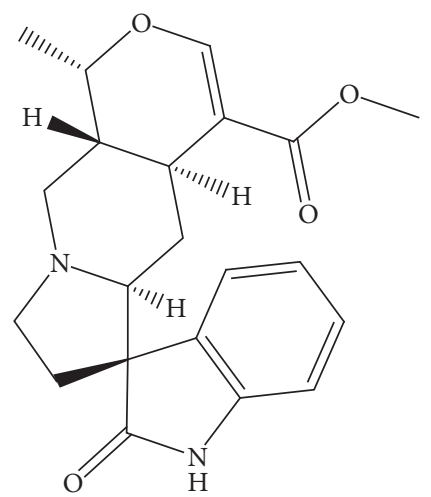

(e)

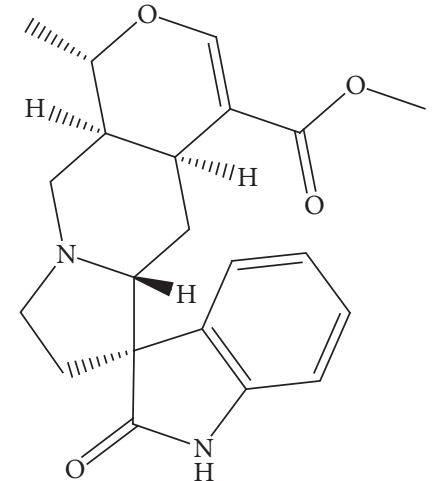

(c)

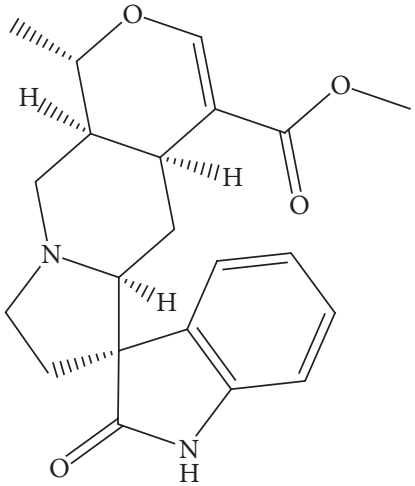

(d)

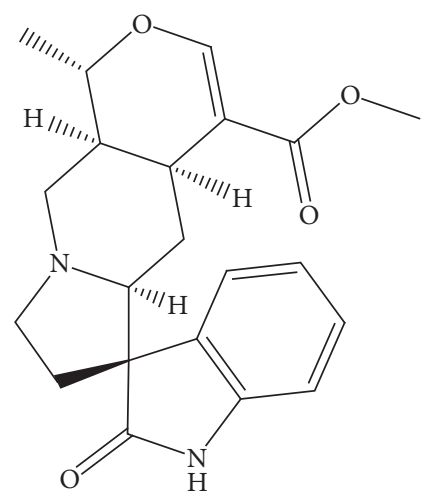

(f)

Figure 4: Structures of metabolites (a) speciophylline (5), (b) mitraphylline (6), (c) uncarine F (7), (d) pteropodine (8), (e) isomitraphylline (9), and (f) isopteropodine (10) present in Uncaria tomentosa (Willd.) DC targeting $\beta$-cells.

insulin secretion. The treatment also increased the expression of IRS-2 and increased the phosphorylation of Akt protein and decreased the protein level of FOXO-1. Furthermore, saponins increased the level of PDX-1. Saponins also increased glucose-stimulated insulin secretion and intracellular insulin content. All these expressions were reversed by phosphoinositide 3-kinase (PI3K) indicating that saponins may increase insulin secretion via the phosphatidylinositol 3-kinase (PI3K)/Akt/FOXO-1 signaling pathway [49].

\subsubsection{Andrographolide-Lipoic Acid Conjugate.} Andrographolide (14) (Figure 5) is a diterpenoid isolated from Andrographis paniculata (Burm. f.) Wall. ex Nees. (Family: Acanthaceae). Conjugation of andrographolide with natural antioxidant lipoic acid at $80 \mathrm{mg} / \mathrm{kg}$ dose was investigated in $\mathrm{BALB} / \mathrm{c}$ mice induced with T1DM by intravenous injection of alloxan $(60 \mathrm{mg} / \mathrm{kg})$ and in RIN-m cell line (an insulinoma cell line). Treatment with the aforementioned compound for six days resulted in increased $\beta$-cell mass in treated mice. Immunohistochemical staining using an anti-insulin antibody showed increased insulincontaining $\beta$-cells. Pretreatment of the $\mathrm{H}_{2} \mathrm{O}_{2}$-treated RIN-m cells with conjugate $(1 \mu \mathrm{M})$ increased the cell viability to $62.2 \%$ and reduced the reactive oxygen species level indicating protection of cells from oxidative stress. At $1 \mu \mathrm{M}$ concentration, this conjugate completely blocked IL- $1 \beta$-and interferon- $\gamma$ (IFN- $\gamma$ ) induced NF- $\kappa \mathrm{B}$ activation thereby protecting $\beta$-cells from apoptosis. [50].

3.2.7. Geniposide. Geniposide (15) (Figure 5), an iridoid glycoside isolated from Gardenia jasminoides Ellis (Family: Rubiaceae), at a dose of $100 \mathrm{mg} / \mathrm{kg}$ given for 56 days was found to be causing $\beta$-cell regeneration in investigations conducted using C57BL/6J mice with DM induced by feeding high-fat diet. Further investigations using Min6 cells revealed that geniposide $(20 \mu \mathrm{M})$ resulted in increased expression of T-cell factor 7-like 2 (TCF7L2), a transcription factor of $\mathrm{Wnt} / \beta$-catenin signaling which involves in $\beta$-cell survival and regeneration. Geniposide promotes $\beta$-cell survival by increasing proliferation of $\beta$-cell and decreasing $\beta$-cell apoptosis in cultured mouse islets after being challenged with diabetic stimuli (glucose/inflammatory cytokines). The compound further activated Akt, enhanced the expressions of GLP-1R inhibited GSK3 $\beta$-activity, and promoted $\beta$-catenin nuclear translocation. Geniposide induced small islet-like cell clusters formation as a result of $\beta$-cell neogenesis from ductal epithelium [51].

3.2.8. Asiatic Acid. Asiatic acid (16) (Figure 5) is a triterpenoid found in plants including Centella asiatica (L.) Urb. (Family: Apiaceae). Wistar rats with DM induced by 
<smiles>OC[C@H]1O[C@H](OCCc2ccc(O)cc2)[C@H](O)[C@H](O)[C@@H]1O</smiles>

(a)<smiles>C=C1CC[C@H]2[C@@](C)(CC[C@@H](O)[C@@]2(C)CO)[C@@H]1C/C=C1/C(=O)OC[C@H]1O</smiles>

(d)<smiles>O=c1c(-c2ccc(O)cc2)coc2c([C@H]3O[C@H](CO)[C@@H](O)[C@H](O)[C@H]3O)c(O)ccc12</smiles>

(b)<smiles>COC(=O)C1=CO[C@@H](O[C@@H]2O[C@H](CO)[C@@H](O)[C@H](O)[C@H]2O)[C@H]2C(CO)=CC[C@H]12</smiles>

(e)<smiles>O=c1cc(-c2ccc(O)cc2)oc2c([C@H]3O[C@H](CO)[C@@H](O)[C@H](O)[C@H]3O)c(O)cc(O)c12</smiles>

(c)

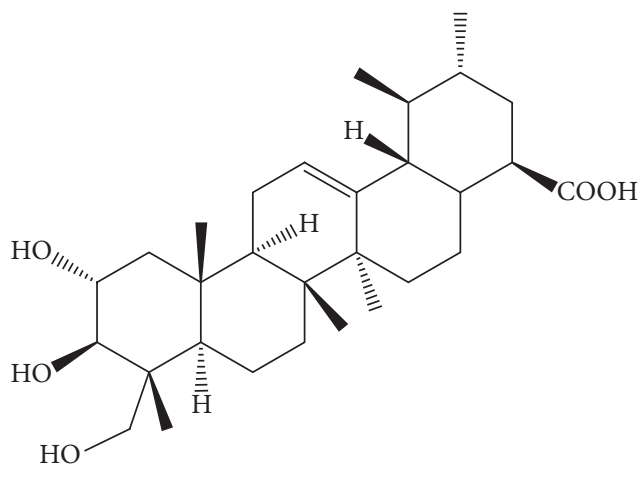<smiles>O=C(O)/C=C/c1ccc(O)c(O)c1</smiles>

(g)

Figure 5: Structures of metabolites (a) salidroside (11), (b) puerarin (12), (c) vitexin (13), (d) andrographolide (14), (e) geniposide (15), (f) asiatic acid (16), and (g) rosmarinic acid (17) isolated from medicinal plants targeting $\beta$-cells.

i.p. injection of STZ $(60 \mathrm{mg} / \mathrm{kg})$ were treated with asiatic acid $(25 \mathrm{mg} / \mathrm{kg})$ for two weeks. Treatment caused improved Akt and $\mathrm{Bcl}-\mathrm{xL}$ expression in the pancreatic islets of rats as evaluated by Western blot methods. Immunohistochemical staining revealed preservation of insulin-producing $\beta$-cells in the pancreatic islets of diabetic rats. Furthermore, asiatic acid resulted in prosurvival Akt kinase activation and BclxL expression in the pancreatic islets of diabetic rats [52].

3.2.9. Angelica sinensis Polysaccharide (ASP). ASP derived from the roots of Angelica sinensis (Oliv.) Diels (Family: Apiaceae) was investigated on pancreatic islets of BALB/c mice with T2DM induced by feeding a high-fat diet followed by i.p. injection of STZ $(60 \mathrm{mg} / \mathrm{kg})$. Treatment with ASP $(100 \mathrm{mg} / \mathrm{kg})$ for eight weeks showed antiapoptotic function on $\beta$-cells via increasing the $\mathrm{Bcl}-2 / \mathrm{Bax}$ ratio thereby blocking caspase-9-caspase-3 cascade. Simultaneous suppression of caspase-8-driven extrinsic apoptotic pathway further inhibited the activation of proteins such as poly (ADP-ribose) polymerase (PARP) involved in $\beta$-cell destruction. Immunohistochemistry and immunocytochemistry indicated that ASP could increase intracellular insulin. ASP also promoted the secretion of insulin by stimulating the insulin gene expression [53].

\subsubsection{Phenylpropenoic Acid Glucoside (PPAG).} Treatment with PPAG isolated from Aspalathus linearis (Burm.f.) R.Dahlgren (Family: Fabaceae) using obese mice fed with a high-fat diet in conjunction with fructose caused tripling of $\beta$-cell mass. Mechanism of the increase of $\beta$-cell mass was investigated by Ki67 immunostaining (an indicator of $\beta$-cell proliferation) and by genetic lineage tracing 
(an indicator of $\beta$-cell neogenesis) of pancreatic tissue, and both were not detected in this case. In contrast, terminal deoxynucleotidyl transferase dUTP nick end labeling (TUNEL) staining which is used to detect DNA breaks formed during the final phase of cell apoptosis revealed suppressed apoptosis in PPAG-treated obese mice. In vitro studies conducted using isolated $\beta$-cells from mice and INS$1 \mathrm{E}$ cell lines showed that PPAG protected $\beta$-cells from palmitate-induced (i.e., a model of lipotoxicity) apoptosis. Exposure of PPAG-treated cells to different stresses revealed that PPAG protected $\beta$-cells against endoplasmic reticulum (ER) stress. Further Western blot analysis revealed that this protection is conferred by increasing the expression of antiapoptotic $\mathrm{Bcl} 2$ protein in $\beta$-cells without affecting proapoptotic signals [54].

In another study, PPAG has investigated in vivo using BALB/c mice induced with DM by i.p. injection of STZ $(200 \mathrm{mg} / \mathrm{kg})$ and in vitro using INS-1E $\beta$-cells and human pancreatic islet cells. Treatment with the PPAG $(10 \mathrm{mg} / \mathrm{kg})$ protected $\beta$-cells from apoptotic cell death and prevented loss of expression of antiapoptotic protein $\mathrm{Bcl} 2$. In vitro studies showed that PPAG protected INS-1E $\beta$-cells from STZ-induced apoptosis in a $\mathrm{Bcl} 2$-dependent and independent way, respectively, depending on glucose concentration. PPAG also protected human pancreatic islets against the cytotoxic action of palmitate [55].

\subsection{Polyherbal Mixtures with Potential for $\beta$-Cell Regeneration} and Function. Sangguayin is a traditional Chinese medicine prepared using the leaf of Morus alba L. (Family: Moraceae), the root of Pueraria lobata (Willd.) Ohwi (Family: Fabaceae), dried rhizoma of Dioscorea opposita Thunb. (Family: Dioscoreaceae), and fruits of Momordica charantia L. (Family: Cucurbitaceae). Sangguayin was investigated using diabetic mice and mouse insulinoma 6 (MIN6) cells for its antiapoptotic action. Treatment with sangguayin $(175 \mathrm{mg} / \mathrm{kg})$ for nine weeks reduced pancreatic pathological changes and islet $\beta$-cell apoptosis in $\mathrm{db} / \mathrm{db}$ diabetic mice. Pretreatment with sangguayin $(25-100 \mu \mathrm{g} / \mathrm{ml})$ resulted in decreased palmitate-induced apoptosis in MIN6 cells. Decreased expression of cleaved PARP, cleaved caspase- 3 , and $\mathrm{Bax}$, and increased $\mathrm{Bcl}-2$ reflected $\beta$-cell survival upon treatment. Furthermore, the treatment suppressed ER stress which was reflected by decreased ER stress pathway-related proteins (Bip/XBP1/IRE1 $\alpha / \mathrm{CHOP} /$ Caspase-12) and autophagy as indicated by downregulation of autophagy-related protein expressions (LC3/p62/Atg5) [56].

Several other polyherbal mixtures were found in the literature as having potential for improving $\beta$-cell regeneration and function. However, the mechanisms of their actions are not yet investigated.

A polyherbal mixture comprised of aqueous extracts of leaves of Murraya koenigii L. (Family: Rutaceae), cloves of Allium sativum L. (Family: Amaryllidaceae), fruits of Garcinia quaesita Pierre (Family: Clusiaceae), and seeds of Piper nigrum L. (Family: Piperaceae) was investigated in Wistar rats with DM induced by i.p. injection of STZ $(70 \mathrm{mg} / \mathrm{kg})$. Oral administration of extract in a dose of $1 \mathrm{~g} / \mathrm{kg}$ for 30 days resulted in improvement of HOMA- $\beta$. Further regeneration of pancreatic $\beta$-cells was observed in histopathological studies [57].

A polyherbal mixture consisting of $95 \%$ ethanol extract of seeds of Nigella sativa L. (Family: Ranunculaceae) and bark of Cinnamomum cassia (L.) D. Don (Family: Lauraceae) was investigated in Wistar rats with DM induced by i.p. injection of STZ $(45 \mathrm{mg} / \mathrm{kg})$. Oral administration of the extract at a dose of $100-200 \mathrm{mg} / \mathrm{kg}$ for 30 days resulted in reversal of STZ-induced pancreatic cell damage as observed from histopathological studies [58].

A polyherbal mixture comprised of $80 \%$ ethanol extract of leaves of Vernonia amygdalina Del. (Family: Asteraceae) and Gongronema latifolium (Utazi) (Family: Apocynaceae) was investigated in albino rats with DM induced by i.p. injection of STZ $(65 \mathrm{mg} / \mathrm{kg})$. Oral administration of the extract at a dose of $200 \mathrm{mg} / \mathrm{kg}$ for 28 days resulted in regeneration of pancreatic $\beta$-cells as evident by histopathological studies [59].

3.4. Clinical Studies on Herbal Medicines with Potential for $\beta$-Cell Regeneration and Function. Only a few clinical studies were reported highlighting the potential for $\beta$-cell regeneration and function by herbal medicines. However, the detailed mechanisms of action of these medicines are yet to be investigated.

Diabetes tea ${ }^{\mathrm{TM}}$, a black tea originating from Camellia sinensis (L.) Kuntze var. sinensis (Family: Theaceae) which is supplemented with 12 other medicinal plants, has been investigated in patients with $\mathrm{T} 2 \mathrm{DM}$ in a double-blind clinical trial. Administration of $2.5 \mathrm{~g}$ of tea powder for 12 weeks resulted in a significant $(p<0.05)$ decrease in $\mathrm{HbA1C}$ and LDL. Furthermore, the treatment caused suppression of CD4+ T-cell expression of IL- $1 \beta$-and IL- 8 and upregulation of the expression of IL-10 and the Treg/IL-17 ratio. Suppression of these proinflammatory cytokines is beneficial for the protection of $\beta$-cells from cytokine-mediated damage [60].

A $70 \%$ ethanol extract of aerial parts of Melissa officinalis L. (Family: Lamiaceae) was investigated in patients with T2DM in a double-blind clinical trial. Rosmarinic acid (17) (Figure 5) was found to be the main component of this extract. Administration of a capsule containing $700 \mathrm{mg}$ of extract for 12 weeks resulted in improvement of $\beta$-cell activity as evident by significant $(p<0.05)$ improvement of HOMA- $\beta$-[61].

A crude drug combination used in traditional Chinese medicine has been investigated in patients with T2DM in a double-blind clinical trial. The crude drug combination consists of Coptis chinensis-rhizome (50\%) and Shen-LingBai-Zhu-San (SLBZS) (50\%). SLBZS consists of Panax ginseng C.A.Mey.-root, Poria cocos (Schw.) Wolf-inner parts of the sclerotia, Atractylodes macrocephala Koidz.-rhizome, Dolichos lablab L.-seed, Dioscorea opposita Thunb.-rhizome, Nelumbo nucifera Gaertn.-seed, Platycodon grandiflorus (Jacq.) A.DC.-root, Coix lacryma-jobi L. var. ma-yuen (Roman.) Stapf-seed, Amomum villosum Lour.-fruit, Ziziphus jujuba Mill.-fruit, and Glycyrrhiza uralensis Fisch.-root 
and rhizome at a $3: 3: 3: 2.3: 3: 1.5: 1.5: 1.5: 1.5: 1.5: 3$ ratio. Oral administration of $9 \mathrm{~g}$ of the above-mentioned combination daily for 12 weeks resulted in increased pancreatic $\beta$-cell function as evident by increased HOMA- $\beta$-value by $68.9 \%[62]$.

Several other plant extracts and isolated compounds exerted antidiabetic effects via targeting $\beta$-cells. However, the mechanisms have not yet been investigated in depth. These are included in Tables 2 and 3, respectively.

\section{Discussion}

A study of 109 full articles published during the last 10 years led to the identification of single herbal extracts, isolated compounds, and polyherbal mixtures derived from approximately 110 medicinal plants belonging to 51 plant families having potential for improving pancreatic $\beta$-cell function and regeneration. The most commonly reported plant families include Fabaceae, Cucurbitaceae, Apocynaceae, Lamiaceae, and Rosaceae. The majority of the investigations were conducted as in vitro and/or preclinical studies. Only $2.8 \%$ of investigations were clinical trials. Hence, there are many unexplored avenues in the topic of this review where future research should be oriented in order to develop safe and effective novel pharmaceuticals/nutraceuticals against diabetes mellitus.

Herbal medicines identified in this review exerted their effects on $\beta$-cells via different mechanisms which are presented in Figure 8. Many herbal medicines reported improvement of $\beta$-cell function as observed through HOMA$\beta$-value (an index of insulin secretory function) derived from fasting plasma glucose and insulin concentrations. Pancreatic $\beta$-cell regeneration was observed in histopathological studies via increase of size and number of pancreatic islets and in immunohistochemical studies via semiquantitative and quantitative estimations of insulin-positive cells and proliferating $\beta$-cells. Western blot analysis and immunohistochemistry to identify transcriptional factors related to gene expressions and other proteins in $\beta$-cell were found to be commonly used in elucidating mechanisms of action of herbal medicines identified in this review. Increasing $\beta$-cell mass via the expression of genes/proteins related to antiapoptotic actions (e.g., Angelica sinensis polysaccharide, vitexin, aqueous extract of Hibiscus rosa sinensis, methanolic extract of Woodfordia fruticosa, salidroside, and sangguayin) and $\beta$-cell neogenesis (e.g., geniposide) and proliferation (e.g., aqueous extract of Cornus officinalis, PPAG) identified as mechanisms of $\beta$-cell regeneration in some herbal products. Apoptosis could occur when the proapoptotic $\mathrm{Bcl}$ 2 proteins (Bad, Bid, Bik, and Bax) exceed antiapoptotic proteins of the $\mathrm{Bcl}$ family (Bcl-2 and $\mathrm{Bcl}-\mathrm{xL}$ ) in the mitochondrial membrane [139]. Increased expression of antiapoptotic proteins with decreased expression of proapoptotic proteins was observed in herbal medicines with antiapoptotic action. Increasing glucose-stimulated insulin secretion via activating GLUT-2 receptors (e.g., methanolic extract of Centaurium erythraea) and increasing intracellular $\mathrm{Ca}^{2+}$ levels (e.g., aqueous extract of Tamarindus indica) were also observed upon treatment with some herbal medicines. Most of the studies suggested that reduction of oxidative stress by natural compounds with antioxidant potential protects $\beta$-cells from damage from reactive oxygen species. Herbal medicines with the ability to reduce proinflammatory cytokines also exerted protective effects on $\beta$-cells. Furthermore, the herbal medicines act on various insulin signaling pathways including activation of PIK3/Akt/ FOXO1 pathways, increasing expression of transcriptional factors AMPK, PDX1, and NFkB, and activation of GLP-1R. However, there are knowledge gaps and unexplored avenues on mechanisms of action of herbal medicines on pancreatic $\beta$-cells which should be further investigated in order to develop effective therapy against DM.

Though the exact cellular and molecular mechanisms of $\beta$-cells causing pathogenesis of diabetes mellitus are still under investigation, certain therapeutic targets in $\beta$-cell for the bioactive compounds have already identified such as nuclear receptors (e.g., peroxisome proliferator-activated receptors (PPARs)), cell membrane receptors (e.g., $\mathrm{K}^{+} / \mathrm{ATP}$ channels, $\mathrm{Na}^{+} / \mathrm{Ca}^{2+}$ exchanger, GLP-1R), transcription factors (e.g., PDX1, Ngn3), and intracellular enzymes (e.g., glucokinase) [140, 141]. Bioactive compounds specifically acting on the aforementioned therapeutic targets could be an effective approach in developing therapies against DM. However, a limited number of publications are available on the structure-activity relationship (SAR) of natural products targeting $\beta$-cells; hence, this aspect needs to be addressed.

It was observed that the majority of the natural bioactive compounds responsible for $\beta$-cell regeneration and improvement of $\beta$-cell function are phenolic compounds including polyphenols such as flavonoids. The SAR of polyphenols as antidiabetic agents is still unclear. However, the occurrence of multiple-OH groups attached to the aromatic ring and the arrangement of these hydroxyls in the ortho-dihydroxy conformation are supposed to be significant structural characteristics for high radical scavenging activity [142]. Most of the polyphenols share those characteristics and hence possess radical scavenging activity. However, the pharmacophore related to antioxidant activity may differ among compounds and hence should be investigated for each compound separately [143]. The amphiphilic nature of most of the polyphenols allows interactions with membrane components at different levels thereby generating cellular responses [144]. In the case of flavonoids, the total number and the configuration of hydroxyl groups are found to be important in regulating antioxidant and antidiabetic properties. C-2-C-3 double bond and C-4 ketonic group are two essential structural features for the antidiabetic property of flavonoids [145].

A limited number of studies have been conducted on SAR of isolated compounds found in this review. Salidroside (11) (Figure 5) is a phenylethanoid glycoside of which the aglycone is a tyrosol. Upon in vivo administration, salidroside gets metabolized into $p$-tyrosol (31) (Figure 9) which accounts for the bioactivity of salidroside [146]. Small peptides (molecular weights of less than $1 \mathrm{kDa}$ ) such as Panax ginseng oligopeptides showed higher antioxidant capacity and strong immunomodulatory action. However, the SAR of oligopeptides is still unclear [147]. Free hydroxyl groups on the $\mathrm{B}$ ring are found to be responsible for the 
TABLE 2: Brief summary of medicinal plant extracts targeting $\beta$-cells via undiscovered mechanisms.

\begin{tabular}{|c|c|c|c|c|c|c|c|}
\hline Plant & Family & $\begin{array}{c}\text { Part of } \\
\text { the plant } \\
\text { used }\end{array}$ & Type of extract & $\begin{array}{c}\text { Secondary } \\
\text { metabolite of } \\
\text { interest }\end{array}$ & $\begin{array}{l}\text { Experimental } \\
\text { model }\end{array}$ & Effects on $\beta$-cells & Reference \\
\hline $\begin{array}{l}\text { Abrus precatorius } \\
\text { L. }\end{array}$ & Fabaceae & Leaves & Ethanol & NM & $\begin{array}{l}\text { Sprague-Dawley } \\
\text { rats induced with } \\
\text { NA ( } 110 \mathrm{mg} / \mathrm{kg} \text {, } \\
\text { i.p.) and STZ } \\
(60 \mathrm{mg} / \mathrm{kg}, \text { i.p. })\end{array}$ & $\begin{array}{c}\text { Recovery of } \\
\text { damaged } \\
\text { pancreatic } \beta \text {-cells } \\
\text { increase in median } \\
\text { cross-sectional } \\
\text { area of pancreatic } \\
\text { islets }\end{array}$ & {$[63]$} \\
\hline $\begin{array}{l}\text { Aegle marmelos } \\
\text { (L.) Corr. Serr. }\end{array}$ & Rutaceae & Leaves & $95 \%$ ethanol & NM & $\begin{array}{c}\text { Albino rats } \\
\text { induced with STZ } \\
\text { (55 mg/kg, i.p.) }\end{array}$ & $\begin{array}{l}\text { Protection of } \\
\text { pancreatic } \beta \text {-cells } \\
\text { from oxidative } \\
\text { stress }\end{array}$ & {$[64]$} \\
\hline $\begin{array}{l}\text { Aegle marmelos } \\
\text { (L.) Corr. Serr. }\end{array}$ & Rutaceae & Bark & Methanol & $\begin{array}{c}\text { Aegelin } \\
\text { (alkaloid) and } \\
\text { lupeol } \\
\text { (triterpenoid) }\end{array}$ & $\begin{array}{c}\text { Wistar rats } \\
\text { induced with STZ } \\
(60 \mathrm{mg} / \mathrm{kg}, \text { i.p. })\end{array}$ & $\begin{array}{c}\text { Regeneration of } \\
\beta \text {-cells } \\
\text { Increase in insulin } \\
\text { producing } \beta \text {-cells }\end{array}$ & {$[65]$} \\
\hline $\begin{array}{l}\text { Aloe vera (L.) } \\
\text { Burm. f. }\end{array}$ & Asphodelaceae & Leaves & Aqueous & NM & $\begin{array}{c}\text { Wistar rats } \\
\text { induced with STZ } \\
\text { (30 mg/kg, i.p.) }\end{array}$ & $\begin{array}{c}\text { Restoration of } \\
\text { pancreatic islet } \\
\text { mass }\end{array}$ & {$[66]$} \\
\hline $\begin{array}{l}\text { Althaea officinalis } \\
\text { L. }\end{array}$ & Malvaceae & Seeds & Methanol & NM & $\begin{array}{c}\text { Wistar rats } \\
\text { induced with STZ } \\
\text { (90 mg/kg, i.p.) }\end{array}$ & $\begin{array}{c}\text { Increase in islet } \\
\text { number and } \\
\text { diameter }\end{array}$ & {$[67]$} \\
\hline $\begin{array}{l}\text { Antidesma bunius } \\
\text { L. }\end{array}$ & Phyllanthaceae & Leaves & Methanol & NM & $\begin{array}{c}\text { Albino mice } \\
\text { induced with } \\
\text { alloxan (150 mg/ } \\
\text { kg, i.p.) }\end{array}$ & $\begin{array}{l}\text { Improvement in } \\
\text { pancreatic } \\
\text { structure } \\
\text { Regeneration of } \\
\text { the } \beta \text {-cells }\end{array}$ & {$[68]$} \\
\hline $\begin{array}{l}\text { Aronia } \\
\text { melanocarpa } \\
\text { (Michx.) Elliott }\end{array}$ & Rosaceae & Fruits & Aqueous & NM & $\begin{array}{c}\text { RINm5F } \\
\text { insulinoma cells }\end{array}$ & $\begin{array}{c}\text { Protection of } \\
\text { pancreatic } \beta \text {-cell } \\
\text { from oxidative } \\
\text { damage }\end{array}$ & {$[69]$} \\
\hline $\begin{array}{l}\text { Artocarpus altilis } \\
\text { (Parkinson) } \\
\text { Fosberg }\end{array}$ & Moraceae & Leaves & Ethanol & NM & $\begin{array}{c}\text { Albino rats } \\
\text { induced with STZ } \\
(50 \mathrm{mg} / \mathrm{kg} \text {, i.p. })\end{array}$ & $\begin{array}{c}\text { Increase in insulin } \\
\text { expression in } \\
\beta \text {-cells } \\
\end{array}$ & {$[70]$} \\
\hline $\begin{array}{l}\text { Aster } \\
\text { spathulifolius } \\
\text { Maxim. }\end{array}$ & Asteraceae & $\begin{array}{l}\text { Whole } \\
\text { plant }\end{array}$ & Ethanol & $\begin{array}{c}3,5-/ 4,5- \\
\text { Dicaffeoylquinic } \\
\text { acid and } \\
\text { chlorogenic acid }\end{array}$ & $\begin{array}{l}\text { C57BL/KsJ-db/db } \\
\text { diabetic mice }\end{array}$ & $\begin{array}{c}\text { Upregulation of } \\
\text { insulin production } \\
\text { by increasing } \\
\text { pancreatic } \beta \text {-cell } \\
\text { mass }\end{array}$ & {$[71]$} \\
\hline $\begin{array}{l}\text { Atriplex } \\
\text { polycarpa (Torr.) } \\
\text { S. Watson }\end{array}$ & Amaranthaceae & $\begin{array}{l}\text { Stem } \\
\text { bark }\end{array}$ & Aqueous & $\begin{array}{l}\text { Alkaloids and } \\
\text { phenolics } \\
\text { (flavonoids) }\end{array}$ & $\begin{array}{l}\text { ICR mice induced } \\
\text { with alloxan } \\
(150 \mathrm{mg} / \mathrm{kg} \text {, i.p. })\end{array}$ & $\begin{array}{c}\text { Regeneration of } \\
\beta \text {-cells }\end{array}$ & {$[72]$} \\
\hline $\begin{array}{l}\text { Azadirachta } \\
\text { indica A. Juss. } \\
\text { Bougainvillea } \\
\text { spectabilis } \text { Willd. }\end{array}$ & $\begin{array}{c}\text { Meliaceae } \\
\text { Nyctaginaceae }\end{array}$ & Leaves & $\begin{array}{l}\text { Chloroform } \\
\text { Aqueous, } \\
\text { Methanol }\end{array}$ & NM & $\begin{array}{c}\text { Swiss mice } \\
\text { induced with STZ } \\
(120 \mathrm{mg} / \mathrm{kg} \text {, i.p.) }\end{array}$ & $\begin{array}{c}\text { Regeneration of } \\
\beta \text {-cells }\end{array}$ & {$[73]$} \\
\hline $\begin{array}{l}\text { Calotropis } \\
\text { gigantean (L.) } \\
\text { W.T. Aiton }\end{array}$ & Apocynaceae & Flowers & Chloroform & NM & $\begin{array}{c}\text { Wistar rats } \\
\text { induced with STZ } \\
(40 \mathrm{mg} / \mathrm{kg} \text {, i.p. })\end{array}$ & $\begin{array}{c}\text { Protection of } \\
\beta \text {-cells from } \\
\text { oxidative stress by } \\
\text { decreasing } \\
\text { pancreatic } \\
\text { thiobarbituric } \\
\text { acid-reactive } \\
\text { substances } \\
\text { (TBARS) levels } \\
\text { increasing the } \\
\text { SOD, CAT, and } \\
\text { GSH levels }\end{array}$ & {$[74]$} \\
\hline
\end{tabular}


TABle 2: Continued.

\begin{tabular}{|c|c|c|c|c|c|c|c|}
\hline Plant & Family & $\begin{array}{c}\text { Part of } \\
\text { the plant } \\
\text { used }\end{array}$ & Type of extract & $\begin{array}{c}\text { Secondary } \\
\text { metabolite of } \\
\text { interest }\end{array}$ & $\begin{array}{l}\text { Experimental } \\
\text { model }\end{array}$ & Effects on $\beta$-cells & Reference \\
\hline $\begin{array}{l}\text { Canscora } \\
\text { decussata (Roxb.) } \\
\text { Schult. }\end{array}$ & Gentianaceae & $\begin{array}{l}\text { Whole } \\
\text { plant }\end{array}$ & Methanol & NM & $\begin{array}{l}\text { Rabbits induced } \\
\text { with alloxan } \\
(150 \mathrm{mg} / \mathrm{kg}, \text { iv })\end{array}$ & $\begin{array}{c}\text { Regeneration of } \\
\beta \text {-cells }\end{array}$ & {$[75]$} \\
\hline $\begin{array}{l}\text { Carica papaya } \\
\text { L. Pandanus } \\
\text { amaryllifolius } \\
\text { Roxb. }\end{array}$ & $\begin{array}{c}\text { Caricaceae } \\
\text { Pandanaceae }\end{array}$ & Leaves & Ethanol & NM & $\begin{array}{c}\text { Mice induced } \\
\text { with STZ }(60 \mathrm{mg} / \\
\text { kg, i.p. })\end{array}$ & $\begin{array}{c}\text { Regeneration of } \\
\beta \text {-cells }\end{array}$ & {$[76]$} \\
\hline $\begin{array}{l}\text { Cassia } \\
\text { occidentalis Linn. }\end{array}$ & Fabaceae & $\begin{array}{l}\text { Whole } \\
\text { plant }\end{array}$ & Ethanol & NM & $\begin{array}{c}\text { Wistar rats } \\
\text { induced with } \\
\text { alloxan }(120 \mathrm{mg} / \\
\text { kg, i.p.) }\end{array}$ & $\begin{array}{c}\text { Regeneration of } \\
\beta \text {-cells }\end{array}$ & {$[77]$} \\
\hline $\begin{array}{l}\text { Chiliadenus } \\
\text { iphionoides } \\
\text { (Boiss. and } \\
\text { Blanche) Brullo }\end{array}$ & Asteraceae & $\begin{array}{c}\text { Aerial } \\
\text { parts }\end{array}$ & $95 \%$ ethanol & NM & $\begin{array}{c}\text { Pancreatic RIN- } \\
\text { 5F cells }\end{array}$ & $\begin{array}{c}\text { Increase in insulin } \\
\text { secretion }\end{array}$ & {$[78]$} \\
\hline $\begin{array}{l}\text { Citrullus } \\
\text { colocynthis (L.) } \\
\text { Schrad. }\end{array}$ & Cucurbitaceae & Seeds & Petroleum ether & NM & $\begin{array}{l}\text { Wistar rats } \\
\text { induced with } \\
\text { alloxan ( } 65 \mathrm{mg} / \\
\text { kg, i.p.) }\end{array}$ & $\begin{array}{c}\text { Partial } \\
\text { preservation/ } \\
\text { restoration of } \\
\text { pancreatic } \beta \text {-cell } \\
\text { mass }\end{array}$ & {$[79]$} \\
\hline $\begin{array}{l}\text { Clitoria ternatea } \\
\text { L. }\end{array}$ & Fabaceae & $\begin{array}{c}\text { Aerial } \\
\text { parts }\end{array}$ & Ethanol & Polyphenols & $\begin{array}{c}\text { Wistar rats } \\
\text { induced with } \\
\text { alloxan }(45 \mathrm{mg} / \\
\mathrm{kg}, \mathrm{sc})\end{array}$ & $\begin{array}{c}\text { Regeneration of } \\
\beta \text {-cells }\end{array}$ & {$[80]$} \\
\hline $\begin{array}{l}\text { Crassocephalum } \\
\text { crepidioides } \\
\text { (Benth.) S. Moore }\end{array}$ & Asteraceae & $\begin{array}{l}\text { Aerial } \\
\text { parts }\end{array}$ & $80 \%$ methanol & NM & $\begin{array}{l}\text { Wistar rats } \\
\text { induced with } \\
\text { alloxan }(150 \mathrm{mg} / \\
\text { kg, i.p.) } \\
\text { INS-1 cells }\end{array}$ & $\begin{array}{l}\text { Increase in the } \\
\text { percentage of } \\
\beta \text {-cells } \\
\text { Protection of } \\
\text { pancreatic } \beta \text {-cell } \\
\text { from alloxan- } \\
\text { induced apoptosis } \\
\text { and from } \\
\text { intracellular } \\
\text { reactive oxygen } \\
\text { species (ROS) } \\
\text { accumulation } \\
\end{array}$ & {$[81]$} \\
\hline $\begin{array}{l}\text { Coccinia grandis } \\
\text { (L.) Voigt }\end{array}$ & Cucurbitaceae & Leaves & Aqueous & NM & $\begin{array}{c}\text { Wistar rats } \\
\text { induced with } \\
\text { alloxan }(150 \mathrm{mg} / \\
\mathrm{kg})\end{array}$ & $\begin{array}{c}\text { Regeneration of } \\
\beta \text {-cells }\end{array}$ & {$[82]$} \\
\hline $\begin{array}{l}\text { Costus igneus } \\
\text { N.E.Br. }\end{array}$ & Costaceae & Rhizome & Ethanol & $\begin{array}{l}\text { Quercetin and } \\
\text { kaempferol } \\
\text { (flavonoids) }\end{array}$ & $\begin{array}{c}\text { Albino rats } \\
\text { induced with STZ } \\
(40 \mathrm{mg} / \mathrm{kg} \text {, i.p. })\end{array}$ & $\begin{array}{c}\text { Regeneration of } \\
\beta \text {-cells }\end{array}$ & [83] \\
\hline Curcuma longa L. & Zingiberaceae & Roots & $\begin{array}{l}\text { Hydroalcoholic } \\
\text { extract }\end{array}$ & NM & $\begin{array}{l}\text { RINm5F cell line } \\
\text { induced with STZ } \\
\qquad(2 \mathrm{mM})\end{array}$ & $\begin{array}{c}\text { Inhibition of } \\
\text { MDA release } \\
\text { Inhibition of } \beta \text {-cell } \\
\text { apoptosis }\end{array}$ & {$[84]$} \\
\hline $\begin{array}{l}\text { Dacryodes edulis } \\
\text { (G. Don) H.J. } \\
\text { Lam }\end{array}$ & Burseraceae & Fruit & Hexane & NM & $\begin{array}{c}\text { Albino rats } \\
\text { induced with } \\
\text { alloxan (150 mg/ } \\
\text { kg, i.p.) }\end{array}$ & $\begin{array}{l}\text { Restoration of the } \\
\text { damaged } \\
\text { pancreatic } \beta \text {-cell } \\
\text { architecture }\end{array}$ & {$[85]$} \\
\hline $\begin{array}{l}\text { Dacryodes edulis } \\
\text { (G. Don) H.J. } \\
\text { Lam }\end{array}$ & Burseraceae & Leaves & Ethanol & $\begin{array}{l}\text { Phenolics-gallic } \\
\text { acid, vanillic acid, } \\
\text { vanillin, and } \\
\text { (-)-epicatechin }\end{array}$ & $\begin{array}{c}\text { Albino rats } \\
\text { induced with } 10 \% \\
\text { fructose and STZ } \\
(40 \mathrm{mg} / \mathrm{kg}, \text { i.p. })\end{array}$ & $\begin{array}{c}\text { Increase in } \\
\text { HOMA- } \beta \\
\text { Improvement in } \\
\text { pancreatic } \\
\text { morphology }\end{array}$ & {$[86]$} \\
\hline
\end{tabular}


TABle 2: Continued.

\begin{tabular}{|c|c|c|c|c|c|c|c|}
\hline Plant & Family & $\begin{array}{c}\text { Part of } \\
\text { the plant } \\
\text { used }\end{array}$ & Type of extract & $\begin{array}{c}\text { Secondary } \\
\text { metabolite of } \\
\text { interest } \\
\end{array}$ & $\begin{array}{l}\text { Experimental } \\
\text { model }\end{array}$ & Effects on $\beta$-cells & Reference \\
\hline $\begin{array}{l}\text { Eriobotrya } \\
\text { japonica (Thunb.) } \\
\text { Lindl. }\end{array}$ & Rosaceae & Leaves & Aqueous & Cinchonain Ib & INS- 1 cell & $\begin{array}{c}\text { Increase in insulin } \\
\text { secretion }\end{array}$ & {$[87]$} \\
\hline $\begin{array}{l}\text { Eurycoma } \\
\text { longifolia Jack }\end{array}$ & Simaroubaceae & Root & NA & NM & $\begin{array}{c}\mathrm{db} / \mathrm{db} \text { diabetic } \\
\text { mice }\end{array}$ & $\begin{array}{c}\text { Proliferation of } \\
\beta \text {-cell and increase } \\
\text { in } \beta \text {-cell number } \\
\text { and PDX1 } \\
\text { expression }\end{array}$ & {$[88]$} \\
\hline Ficus carica $\mathrm{L}$. & Moraceae & Leaves & Ethyl acetate & NM & $\begin{array}{l}\text { Wistar rats } \\
\text { induced with } \\
\text { HFD and STZ } \\
\text { (40 mg/kg, i.p.) }\end{array}$ & $\begin{array}{c}\text { Protection of } \\
\beta \text {-cells from } \\
\text { oxidative stress } \\
\text { Improvement of } \\
\text { OGTT and ITT }\end{array}$ & [89] \\
\hline $\begin{array}{l}\text { Gastrodia elata } \\
\text { Blume }\end{array}$ & Orchidaceae & $\begin{array}{l}\text { Whole } \\
\text { plant }\end{array}$ & Aqueous & NM & $\begin{array}{c}\text { Sprague-Dawley } \\
\text { rats induced by } \\
90 \% \\
\text { pancreatectomy }\end{array}$ & $\begin{array}{c}\text { Induction of } \\
\text { hypothalamic } \\
\text { insulin signaling } \\
\text { Increase in mass of } \\
\beta \text {-cells by } \\
\text { potentiating } \\
\text { proliferation and } \\
\text { decreasing } \\
\text { apoptosis } \\
\end{array}$ & {$[90]$} \\
\hline $\begin{array}{l}\text { Gossypium } \\
\text { herbaceum L. }\end{array}$ & Malvaceae & Seeds & Ethanol & NM & $\begin{array}{l}\text { Rabbits induced } \\
\text { with alloxan- } \\
\text { induced (100 mg/ } \\
\text { kg, iv) diabetic } \\
\text { rabbits }\end{array}$ & $\begin{array}{c}\text { Protection of } \\
\beta \text {-cells from } \\
\text { oxidative stress }\end{array}$ & [91] \\
\hline $\begin{array}{l}\text { Gmelina arborea } \\
\text { Roxb. }\end{array}$ & Verbenaceae & $\begin{array}{l}\text { Stem } \\
\text { bark }\end{array}$ & Aqueous & NM & $\begin{array}{c}\text { Wistar rats } \\
\text { induced with } \\
\text { alloxan ( } 150 \mathrm{mg} / \\
\mathrm{kg} \text {, i.p.) } \\
\text { Wistar rats } \\
\text { induced with STZ } \\
\text { (65 mg/kg, i.p.) }\end{array}$ & $\begin{array}{c}\text { Regeneration of } \\
\beta \text {-cells } \\
\text { Regeneration of } \\
\beta \text {-cells }\end{array}$ & {$[82,92]$} \\
\hline $\begin{array}{l}\text { Gymnema } \\
\text { montanum } \\
\text { (Roxb.) Hook.f. } \\
\text { var. montanum }\end{array}$ & Apocynaceae & Leaves & Ethanol & NM & $\begin{array}{l}\text { HIT-T15 } \beta \text {-cell } \\
\text { line }\end{array}$ & $\begin{array}{c}\text { Protection of } \\
\text { pancreatic } \beta \text {-cells } \\
\text { from alloxan- } \\
\text { induced oxidative } \\
\text { stress }\end{array}$ & {$[93]$} \\
\hline $\begin{array}{l}\text { Gymnema } \\
\text { sylvestre (Retz.) } \\
\text { Schult. }\end{array}$ & Apocynaceae & $\begin{array}{l}\text { Leaf and } \\
\text { callus }\end{array}$ & Methanol & Gymnemic acid & $\begin{array}{c}\text { Wistar rats } \\
\text { induced with } \\
\text { alloxan (100 mg/ } \\
\text { kg, i.p.) }\end{array}$ & $\begin{array}{c}\text { Regeneration of } \\
\beta \text {-cells }\end{array}$ & {$[94]$} \\
\hline $\begin{array}{l}\text { Hibiscus } \\
\text { sabdariffa L. }\end{array}$ & Malvaceae & Calyx & Methanol & NM & $\begin{array}{c}\text { Wistar rats } \\
\text { induced with STZ } \\
(80 \mathrm{mg} / \mathrm{kg} \text {, i.p. })\end{array}$ & $\begin{array}{l}\text { Improvement of } \\
\text { the volume of the } \\
\text { pancreatic islets } \\
\text { and the numerical } \\
\text { density of } \beta \text {-cell } \\
\text { (number of } \beta \text {-cells } \\
\text { per unit area of } \\
\text { islet) }\end{array}$ & {$[95]$} \\
\hline $\begin{array}{l}\text { Hypoxis argentea } \\
\text { Harv. ex Baker }\end{array}$ & Hypoxidaceae & Corms & Aqueous & NM & INS- 1 cells & $\begin{array}{c}\text { A significant } \\
(p<0.001) \\
\text { increase in total } \\
\text { INS-1 cell } \\
\text { numbers }\end{array}$ & {$[96]$} \\
\hline
\end{tabular}


TABle 2: Continued.

\begin{tabular}{|c|c|c|c|c|c|c|c|}
\hline Plant & Family & $\begin{array}{c}\text { Part of } \\
\text { the plant } \\
\text { used }\end{array}$ & Type of extract & $\begin{array}{c}\text { Secondary } \\
\text { metabolite of } \\
\text { interest } \\
\end{array}$ & $\begin{array}{l}\text { Experimental } \\
\text { model }\end{array}$ & Effects on $\beta$-cells & Reference \\
\hline $\begin{array}{l}\text { Ichnocarpus } \\
\text { frutescens (L.) } \\
\text { W.T.Aiton }\end{array}$ & Apocynaceae & $\begin{array}{l}\text { Leaves, } \\
\text { stem, and } \\
\text { flowers }\end{array}$ & Methanol & NM & $\begin{array}{c}\text { Wistar rats } \\
\text { induced with NA } \\
(230 \mathrm{mg} / \mathrm{kg} \text {, i.p. }) \\
\text { and STZ (65 mg/ } \\
\text { kg, i.p.) }\end{array}$ & $\begin{array}{c}\text { Regeneration of } \\
\beta \text {-cells }\end{array}$ & [97] \\
\hline $\begin{array}{l}\text { Khaya } \\
\text { senegalensis } \\
\text { (Desr.) A. Juss. }\end{array}$ & Meliaceae & Root & $\begin{array}{c}\text { Butanol fraction } \\
\text { of ethanol } \\
\text { extract }\end{array}$ & $\mathrm{NM}$ & $\begin{array}{l}\text { Sprague-Dawley } \\
\text { rats induced with } \\
\text { fructose }(10 \%) \\
\text { and STZ (40 mg/ } \\
\text { kg, i.p.) }\end{array}$ & $\begin{array}{c}\text { Improvement in of } \\
\text { HOMA- } \beta\end{array}$ & {$[98]$} \\
\hline Laurus nobilis L. & Lauraceae & Leaves & Ethanol & NM & $\begin{array}{c}\text { Wistar rats } \\
\text { induced with STZ } \\
\text { (70 mg/kg, i.p.) }\end{array}$ & $\begin{array}{l}\text { Regeneration of } \\
\text { pancreatic islets }\end{array}$ & [99] \\
\hline $\begin{array}{l}\text { Leea macrophylla } \\
\text { (Roxb.) ex } \\
\text { Hornem }\end{array}$ & Vitaceae & Root & Ethanol & NM & $\begin{array}{c}\text { Wistar rats } \\
\text { induced with STZ } \\
(60 \mathrm{mg} / \mathrm{kg} \text {, i.p. })\end{array}$ & $\begin{array}{c}\text { Reduction of } \\
\text { oxidative stress } \\
\text { Repair of } \beta \text {-cell } \\
\text { damage } \\
\end{array}$ & {$[100]$} \\
\hline $\begin{array}{l}\text { Mangifera indica } \\
\text { L. }\end{array}$ & Anacardiaceae & Leaves & Alcohol & NM & $\begin{array}{l}\text { Swiss albino mice } \\
\text { induced with } \\
\text { alloxan (150 mg/ } \\
\text { kg, i.p.) }\end{array}$ & $\begin{array}{c}\text { Regeneration of } \\
\beta \text {-cells }\end{array}$ & [101] \\
\hline $\begin{array}{l}\text { Momordica } \\
\text { charantia L. }\end{array}$ & Cucurbitaceae & $\begin{array}{l}\text { Fruit } \\
\text { pulp }\end{array}$ & Ethanol & NM & $\begin{array}{c}\text { Wistar rats } \\
\text { induced with STZ } \\
(100 \mathrm{mg} / \mathrm{kg} \text {, i.p. })\end{array}$ & $\begin{array}{l}\text { Improvement of } \\
\text { HOMA- } \beta \\
\text { Increase in islet } \\
\text { size, total } \beta \text {-cell } \\
\text { area and number } \\
\text { of insulin-positive } \\
\quad \beta \text {-cells }\end{array}$ & {$[102]$} \\
\hline $\begin{array}{l}\text { Momordica } \\
\text { charantia L. }\end{array}$ & Cucurbitaceae & Fruit & NA & NM & $\begin{array}{c}\text { Wistar rats } \\
\text { induced with } \\
\text { HFD and STZ } \\
(40 \mathrm{mg} / \mathrm{kg} \text {, i.p. })\end{array}$ & $\begin{array}{c}\text { Regeneration of } \\
\beta \text {-cells }\end{array}$ & [103] \\
\hline $\begin{array}{l}\text { Momordica } \\
\text { charantia L. }\end{array}$ & Cucurbitaceae & Fruit & Aqueous & NM & $\begin{array}{c}\text { Albino rats } \\
\text { induced with STZ } \\
\text { (55 mg/kg, i.p.) }\end{array}$ & $\begin{array}{c}\text { Regeneration of } \\
\beta \text {-cells }\end{array}$ & {$[104]$} \\
\hline $\begin{array}{l}\text { Moringa oleifera } \\
\text { Lam. }\end{array}$ & Moringaceae & Leaves & Aqueous & $\mathrm{NM}$ & $\begin{array}{c}\text { Wistar rats } \\
\text { induced with } \\
\text { alloxan (120 mg/ } \\
\text { kg, i.p.) }\end{array}$ & $\begin{array}{c}\text { Regeneration of } \\
\text { damaged } \\
\text { hepatocytes and } \\
\text { pancreatic } \beta \text {-cells }\end{array}$ & [105] \\
\hline $\begin{array}{l}\text { Nypa } \\
\text { fruticans Wurmb. }\end{array}$ & Arecaceae & Vinegar & Aqueous & NM & $\begin{array}{l}\text { Sprague-Dawley } \\
\text { rats induced with } \\
\text { STZ ( } 55 \mathrm{mg} / \mathrm{kg} \text {, } \\
\text { i.p.) } \\
\text { RIN-5F cell } \\
\text { culture }\end{array}$ & $\begin{array}{l}\text { Increase in insulin } \\
\text { production } \\
\text { Stimulatory effect } \\
\text { on insulin release } \\
\text { at a basal glucose } \\
\text { concentration } \\
(1.1 \mathrm{mM})\end{array}$ & [106] \\
\hline $\begin{array}{l}\text { Otostegia persica } \\
\text { Boiss }\end{array}$ & Lamiaceae & $\begin{array}{c}\text { Aerial } \\
\text { parts }\end{array}$ & Methanol & $\mathrm{NM}$ & $\begin{array}{c}\text { C187 pancreatic } \\
\beta \text {-cells }\end{array}$ & Increase in GSIS & [107] \\
\hline $\begin{array}{l}\text { Parkia biglobosa } \\
\text { (Jacq.) G. Don }\end{array}$ & Fabaceae & Leaves & Butanol fraction & NM & $\begin{array}{l}\text { Sprague-Dawley } \\
\text { rats induced with } \\
\text { STZ ( } 40 \mathrm{mg} / \mathrm{kg} \text {, } \\
\text { i.p.) }\end{array}$ & $\begin{array}{c}\text { Improvement of } \\
\text { HOMA- } \beta\end{array}$ & [108] \\
\hline $\begin{array}{l}\text { Phyllanthus } \\
\text { emblica L. }\end{array}$ & Phyllanthaceae & Fruits & $\begin{array}{l}\text { Hydroalcoholic } \\
\text { extract }\end{array}$ & $\mathrm{NM}$ & $\begin{array}{l}\text { RINm5F cell line } \\
\text { induced with STZ } \\
\qquad(2 \mathrm{mM})\end{array}$ & $\begin{array}{c}\text { Inhibition of } \\
\text { MDA release } \\
\text { Inhibition of } \beta \text {-cell } \\
\text { apoptosis }\end{array}$ & {$[84]$} \\
\hline
\end{tabular}


TABle 2: Continued.

\begin{tabular}{|c|c|c|c|c|c|c|c|}
\hline Plant & Family & $\begin{array}{l}\text { Part of } \\
\text { the plant } \\
\text { used }\end{array}$ & Type of extract & $\begin{array}{c}\text { Secondary } \\
\text { metabolite of } \\
\text { interest } \\
\end{array}$ & $\begin{array}{l}\text { Experimental } \\
\text { model }\end{array}$ & Effects on $\beta$-cells & Reference \\
\hline $\begin{array}{l}\text { Prosopis cineraria } \\
\text { (L.) Druce }\end{array}$ & Fabaceae & Pods & Ethanol & NM & $\begin{array}{c}\text { Albino rats } \\
\text { induced with high } \\
\text { sucrose diet and } \\
\text { dexamethasone } \\
(1.5 \mathrm{mg} / \mathrm{kg} \text {, i.p. })\end{array}$ & $\begin{array}{c}\text { Increase in } \\
\text { HOMA- } \beta \text {-increase } \\
\text { in pancreatic cell } \\
\text { proliferation }\end{array}$ & [109] \\
\hline $\begin{array}{l}\text { Pseuduvaria } \\
\text { macrophylla } \\
\text { (Oliv.) Merr. }\end{array}$ & Annonaceae & $\begin{array}{l}\text { Stem } \\
\text { bark }\end{array}$ & $\begin{array}{l}\text { Methanol and } \\
\text { chloroform }\end{array}$ & Polyphenols & $\begin{array}{l}\text { Sprague-Dawley } \\
\text { rats induced with } \\
\text { NA ( } 210 \mathrm{mg} / \mathrm{kg} \text {, } \\
\text { i.p.) and STZ } \\
\text { (55 mg/kg, i.p.) }\end{array}$ & $\begin{array}{c}\text { Reduction of } \\
\text { oxidative stress } \\
\text { Downregulation } \\
\text { of the levels of } \\
\text { proinflammatory } \\
\text { cytokines }\end{array}$ & {$[110]$} \\
\hline $\begin{array}{l}\text { Spondias pinnata } \\
\text { (Linn. f.) Kurz }\end{array}$ & Anacardiaceae & $\begin{array}{l}\text { Stem } \\
\text { bark }\end{array}$ & Aqueous & NM & $\begin{array}{c}\text { Wistar rats } \\
\text { induced with } \\
\text { alloxan }(150 \mathrm{mg} / \\
\mathrm{kg})\end{array}$ & $\begin{array}{c}\text { Regeneration of } \\
\beta \text {-cells }\end{array}$ & {$[82]$} \\
\hline $\begin{array}{l}\text { Spondias pinnata } \\
\text { (Linn. f.) Kurz. }\end{array}$ & Anacardiaceae & $\begin{array}{l}\text { Stem } \\
\text { bark }\end{array}$ & Aqueous & NM & $\begin{array}{c}\text { Wistar rats } \\
\text { induced with STZ } \\
\text { (65 mg/kg, i.p.) }\end{array}$ & $\begin{array}{c}\text { Islet cell } \\
\text { regeneration as } \\
\text { noted by the } \\
\text { increase in } \\
\text { insulin-secreting } \\
\beta \text {-cells and } \\
\text { increase in islet } \\
\text { profile diameter in } \\
\text { the pancreas }\end{array}$ & [111] \\
\hline $\begin{array}{l}\text { Syzygium } \\
\text { densiflorum Wall. } \\
\text { ex Wight and Arn }\end{array}$ & Myrtaceae & Fruits & Methanol & NM & $\begin{array}{c}\text { Wistar rats } \\
\text { induced with NA } \\
\text { (110 mg/kg, i.p.) } \\
\text { and STZ (65 mg/ } \\
\text { kg, i.p.) }\end{array}$ & $\begin{array}{c}\text { Regeneration of } \\
\beta \text {-cells }\end{array}$ & [112] \\
\hline $\begin{array}{l}\text { Swertia } \\
\text { macrosperma } \\
\text { C.B.Clarke }\end{array}$ & Gentianaceae & $\begin{array}{l}\text { Whole } \\
\text { plant }\end{array}$ & $90 \%$ ethanol & Polyphenols & $\begin{array}{c}\text { Wistar rats } \\
\text { induced with } \\
\text { high-fat-high } \\
\text { fructose diet and } \\
\text { STZ ( } 35 \mathrm{mg} / \mathrm{kg} \text {, } \\
\text { i.p.) }\end{array}$ & $\begin{array}{c}\text { Protection of } \\
\text { pancreatic } \beta \text {-cells } \\
\text { from oxidative } \\
\text { stress } \\
\text { Stimulation of } \\
\text { insulin secretion } \\
\text { from the } \\
\text { remaining } \\
\text { pancreatic } \beta \text {-cells }\end{array}$ & {$[113]$} \\
\hline $\begin{array}{l}\text { Tamarindus } \\
\text { indica L. }\end{array}$ & Fabaceae & Seed coat & $95 \%$ ethanol & Polyphenols & $\begin{array}{c}\text { Wistar rats } \\
\text { induced with } \\
\text { alloxan (120 mg/ } \\
\text { kg, i.p.) }\end{array}$ & $\begin{array}{c}\text { Protection of } \\
\text { pancreatic } \beta \text {-cells } \\
\text { from oxidative } \\
\text { stress }\end{array}$ & {$[114]$} \\
\hline $\begin{array}{l}\text { Tamarix stricta } \\
\text { Boiss. }\end{array}$ & Tamaricaceae & $\begin{array}{c}\text { Aerial } \\
\text { parts }\end{array}$ & $70 \%$ ethanol & NM & $\begin{array}{c}\text { Pancreatic RIN- } \\
\text { 5F cells } \\
\text { Albino BALB/c } \\
\text { mice induced } \\
\text { with HFD and } \\
\text { STZ ( } 40 \mathrm{mg} / \mathrm{kg} \text {, } \\
\text { i.p.) } \\
\end{array}$ & $\begin{array}{c}\text { Preservation of } \\
\beta \text {-cells }\end{array}$ & {$[115]$} \\
\hline $\begin{array}{l}\text { Teucrium polium } \\
\text { L. }\end{array}$ & Lamiaceae & Methanol & Methanol & $\begin{array}{l}\text { Rutin and } \\
\text { apigenin } \\
\text { (flavonoids) }\end{array}$ & $\begin{array}{c}\text { Isolated rat } \\
\text { pancreatic islets }\end{array}$ & $\begin{array}{l}\text { Increase in insulin } \\
\text { release }\end{array}$ & [116] \\
\hline $\begin{array}{l}\text { Tinospora } \\
\text { cordifolia } \\
\text { (Thunb.) Miers }\end{array}$ & Menispermaceae & Stem & $\begin{array}{l}\text { Hexane, ethyl } \\
\text { acetate, and } \\
\text { methanol }\end{array}$ & NM & $\begin{array}{c}\text { Albino rats } \\
\text { induced with STZ } \\
\text { (55 mg/kg, i.p.) }\end{array}$ & $\begin{array}{c}\text { Regeneration of } \\
\beta \text {-cell }\end{array}$ & [117] \\
\hline
\end{tabular}


TABLE 2: Continued.

\begin{tabular}{|c|c|c|c|c|c|c|c|}
\hline Plant & Family & $\begin{array}{l}\text { Part of } \\
\text { the plant } \\
\text { used }\end{array}$ & Type of extract & $\begin{array}{c}\text { Secondary } \\
\text { metabolite of } \\
\text { interest }\end{array}$ & $\begin{array}{l}\text { Experimental } \\
\text { model }\end{array}$ & Effects on $\beta$-cells & Reference \\
\hline $\begin{array}{l}\text { Tinospora cord } \\
\text { folia (Thunb.) } \\
\text { Miers }\end{array}$ & Menispermaceae & Stems & $\begin{array}{l}\text { Hydroalcoholic } \\
\text { extract }\end{array}$ & NM & $\begin{array}{l}\text { RINm5F cell line } \\
\text { induced with STZ } \\
\qquad(2 \mathrm{mM})\end{array}$ & $\begin{array}{c}\text { Inhibition of } \\
\text { MDA release } \\
\text { Inhibition of } \beta \text {-cell } \\
\text { apoptosis }\end{array}$ & {$[84]$} \\
\hline Urena lobata L. & Malvaceae & Leaves & Aqueous & NM & $\begin{array}{c}\text { Sprague-Dawley } \\
\text { rats induced with } \\
\text { high fructose diet } \\
\text { and STZ ( } 25 \mathrm{mg} / \\
\text { kg, i.p.) }\end{array}$ & $\begin{array}{l}\text { Improvement in } \\
\text { the structure and } \\
\text { function of } \beta \text {-cells } \\
\text { Prevention of } \\
\text { degradation of } \\
\text { GLP-1 by } \\
\text { inhibition of DPP- } \\
4 \text { activity }\end{array}$ & [118] \\
\hline Urtica dioica $\mathrm{L}$. & Urticaceae & Leaves & $90 \%$ ethanol & NM & $\begin{array}{c}\text { Wistar rats } \\
\text { induced with STZ } \\
\text { (50 mg/kg, i.p.) } \\
\text { RIN-5F cells }\end{array}$ & $\begin{array}{l}\text { Regeneration of } \\
\beta \text {-cells and } \\
\text { reduction of } \beta \text {-cell } \\
\text { damage } \\
\text { Increase in insulin } \\
\text { secretion }\end{array}$ & [119] \\
\hline $\begin{array}{l}\text { Vitex doniana } \\
\text { Sweet. }\end{array}$ & Verbenaceae & Leaves & $\begin{array}{l}\text { Aqueous and } \\
\text { ethanol }\end{array}$ & NM & $\begin{array}{c}\text { Albino rats } \\
\text { induced with STZ } \\
(60 \mathrm{mg} / \mathrm{kg}, \text { i.p. })\end{array}$ & $\begin{array}{l}\text { Regeneration of } \\
\beta \text {-cells along with } \\
\text { repair of } \beta \text {-cells }\end{array}$ & {$[120]$} \\
\hline $\begin{array}{l}\text { Vitellaria } \\
\text { paradoxa C.F. } \\
\text { Gaertn. }\end{array}$ & Sapotaceae & Barks & Aqueous & NM & $\begin{array}{c}\text { Wistar rats } \\
\text { induced with } \\
\text { HFD and STZ } \\
\text { (35 mg/kg, i.p.) }\end{array}$ & $\begin{array}{l}\text { Increase in the size } \\
\text { and number of } \\
\text { islets in the } \\
\text { pancreas }\end{array}$ & [121] \\
\hline $\begin{array}{l}\text { Zingiber officinale } \\
\text { Roscoe }\end{array}$ & Zingiberaceae & Rhizome & $\begin{array}{c}96 \% \text { ethanol and } \\
\text { supercritical } \\
\mathrm{CO}_{2} \text { extracts }\end{array}$ & NM & INS-1 cells & $\begin{array}{l}\text { Modulation of } \\
\text { insulin release by } \\
\text { interacting with } \\
\text { serotonin ( } 5-\mathrm{HT}) \\
\text { receptor channel } \\
\text { system }\end{array}$ & [122] \\
\hline
\end{tabular}

DM, diabetes mellitus; STZ, streptozotocin; NA, nicotinamide; i.p., intraperitoneal; iv, intravenous; sc, subcutaneous; HFD, high-fat diet; homeostatic model assessment- $\beta$-cell function HOMA- $\beta$; malondialdehyde, MDA; superoxide dismutase, SOD; neurogenin 3, Ngn3; natural killer cell transcription factorrelated, gene family 6, locus 1, Nkx6.1; TBARS, thiobarbituric acid-reactive substances; CAT, catalase; GSH, reduced glutathione; ROS, reactive oxygen species; PDX1, pancreatic duodenal homeobox-1; OGTT, oral glucose tolerance test; ITT, GSIS, glucose-stimulated insulin secretion; GLP-1, glucagon-like peptide-1; DPP-4, dipeptidyl peptidase inhibitor-4; 5-HT, serotonin; NA, not applicable; NM, not mentioned.

antioxidant properties of $C$-glycosylflavones such as vitexin (13) (Figure 5) [148]. C-glycosides such as vitexin and $O$ glycosides such as salidroside (11) exert similar biological effects. However, both vitexin and $\mathrm{O}$-glycosides have poor water solubility. Hence, modification of glycosidic bonds to improve water solubility would lead to improved bioavailability [149].

SAR studies reported on several other compounds are also noteworthy to identify pharmacophores targeting $\beta$-cells. A SAR study on oleuropein (32) (Figure 9) (a secoiridoid glycoside) isolated from leaves of Olea europaea (Family: Oleaceae) reported that 3-hydroxytyrosol moiety of oleuropein is the main entity responsible for amyloid inhibition. However, the entire structure scaffold of the molecule was found to be needed for its glucose-stimulated insulin secretion effect [150]. SAR study of a cinnamic acid derivative, (E)-3-(3-phenylbenzo[c]isoxazol-5-yl)acrylic acid (33) (Figure 9), with $\beta$-cell regeneration ability has shown the presence of both carboxylate group and the intact isoxazolyl ring required for its $\beta$-cell regeneration ability via
cAMP/PKA/mTOR signaling pathway by inhibiting IKK and $\mathrm{Ikb}$ selectively in $\beta$-cells [151]. SAR optimization of a 2,4-diaminoquinazoline (34) (Figure 9) compound showed antiapoptotic action and increased insulin secretion which were mediated by regulating genes related to signaling pathways of caspase- 3 and PDX1/MafA, respectively. These effects were optimum when 4-methoxy and benzylamine groups are present in the molecule [152]. Apart from the above, attempts have been made to identify potential $\beta$-cell targets of isolated compounds from medicinal plants through molecular docking studies. Data of molecular docking studies could be used in selecting potential antidiabetic agents for further in vivo/in vitro investigations. Herbacetin (35) (Figure 9) and sorbifolin (36) (Figure 9) isolated from Ficus species are capable of binding to amino acid residues Leu1002, Met1079, and Asp1150 of insulin receptor [153]. Glycogen synthase kinase-3 (GSK-3) is an important target in the regulation of $\beta$-cell mass and regeneration. Docking study on $(4 Z, 12 Z)$-cyclopentadeca- 
4,12-dienone (37) (Figure 9) isolated from Grewia hirsuta against target protein GSK-3 has shown that the oxygen atom of the isolated compound reacts with LYS-85 residue of GSK-3 and forms hydrogen bond through a strong hydrophobic interaction [154]. Quercetin (22) (Figure 6), iristectorigenin A (38), 4-prenylresveratrol (39), moracin $\mathrm{H}$ (40), moracin C (41), isoramanone (42), moracin E (43), and moracin D (44) (Figure 10) isolated from leaves of Morus alba Linne have shown good affinity to AKT-1 target protein [155].

Molecular docking and SAR studies conducted on compounds of different chemical categories are also reported, and these data could be useful in predicting activities of natural compounds with related structures. One such SAR study on benzamide derivatives reported that 3-( $N$-piperidinyl) methylbenzamide derivative protects $\beta$-cells against ER stress-induced dysfunction and death [156]. Virtual screening of thiadiazine compounds against dual-specificity tyrosine-phosphorylation-regulated kinase 1A (DYRK1A) enzyme has shown to be capable of inducing $\beta$-cell replication [157]. SAR optimization of harmine analogs revealed that derivatives of harmine with $\mathrm{C}-1$ position substitutions act on DYRK1A promoting human $\beta$-cell proliferation at doses of 3-30 $\mu \mathrm{M}$ [158].

\section{Toxicity Concerns of Herbal Medicines Targeting $\beta$-Cells}

Herbal medicines with a long history of use for DM are considered to be safe for therapeutic applications. Single herbal extracts and polyherbal mixtures as used by traditional medicine practitioners are generally considered to be time tested for safety and hence are allowed to be used directly in clinical applications [159]. However, fractionation or isolation of compounds from plant extracts may lead to toxicities [160]. The intention of coadministration of herbs or herbal compounds in traditional medicine practices is to have a synergistic therapeutic effect while ameliorating toxicities exerted by individual herbs. Scientific investigations in favor of combination therapy of different herbs to reduce toxicity exerted from individual herbs are also reported. Such attenuations in toxicities are usually caused by herb-herb interactions in polyherbal mixtures or mixtures of herbal compounds which leads to alterations of pharmacokinetics, i.e., absorption, distribution, metabolism, and elimination of constituents [161]. For example, Fructus Foeniculi (mature fruit of Foeniculum vulgare Mill.) and Fructus Meliae Toosendan (mature fruit of Melia toosendan Sieb. et Zucc) are two herbs used in combination in traditional Chinese medicine, and pharmacokinetic studies have revealed that Fructus Foeniculi attenuates the hepatotoxicity exerted by Fructus Meliae Toosendan via decreasing its absorption and increasing elimination thereby decreasing in vivo accumulation of the toxic constituent, toosendanin [162]. However, there is a possibility of occurring undesirable alterations of pharmacokinetics upon concomitant administration of different herbs especially in the case of introducing novel herbal mixtures. This could lead to unexpected toxicities by means such as accumulation of herbal constituents in the body or formation of toxic metabolites. For example, herbal compounds with cytochrome p450 inhibitory activity may diminish the metabolism of another coadministered herbal compound metabolizing via the same enzyme leading to toxicity from the latter [163]. For example, pyrrolizidine alkaloids are reported to exert hepatotoxicity and genotoxicity by metabolic activation via cytochrome p450 enzyme and modulate other hepatic metabolizing enzymes and hence could produce unexpected toxicities when coadministered with other herbal compounds with hepatic enzyme modulatory effect [164]. Most of the herbal medicines discussed in this review were tested using in vitro cellular models and rats for their toxicity and were proven to be safe. However, natural products usually have multiple bioactivities which may include unwanted/toxic effects when it comes to clinical applications. For example, asiatic acid found in this review also possesses anticancer activity where it inhibits antiapoptotic proteins causing cell death [165].

Extensive toxicity studies including in vivo acute and repeated dose toxicity, in vitro cytotoxicity, genotoxicity, carcinogenicity, teratogenicity, and drug interaction studies are required to ensure the safety of traditional herbal medicines [166]. Hence, in-depth long-term toxicity studies using in vivo models are warranted to ascertain the safety of herbal medicines as therapeutics. Apart from that, contamination of herbal medicines with heavy metals such as lead, arsenic, mercury, and cadmium which may lead to toxicity in consumers is a matter of concern [167]. Hence, standardization of herbal medicines using limited tests for these heavy metals is also needed.

\section{Challenges and Future Perspectives}

Herbal medicines due to their multitasking ability and low toxicity (at prescribed doses) compared to synthetic medicines could be useful in addressing therapeutic needs of multifactorial diseases such as DM that have not yet been met by synthetic medicines. There is a vast knowledge of herbal medicines with antidiabetic effects residing among different nations and ethnic groups. Retrieval of this information would pave the way to develop better therapeutic agents for DM particularly targeting the $\beta$-cell functions.

An increasing trend of investigating herbal medicines targeting pancreatic $\beta$-cells as a preventive/treatment strategy for DM is observed in recent years. However, longterm in vivo/in vitro investigations on determining biological effects and toxicities as well as elucidating molecular and cellular mechanisms are needed to ensure the safety and efficacy of these products.

The involvement of $\beta$-cells in disease pathogenesis and identification of molecular and cellular targets of $\beta$-cells for effective treatment of DM has also extensively been studied. Hence, elucidation of SAR of natural bioactive compounds targeting $\beta$-cells is important in identifying/developing lead compounds in the development of novel therapeutic options against DM.

The low aqueous solubility, poor absorption leading to low bioavailability, unpleasant taste, and lack of 
TABLE 3: Plant secondary metabolites targeting $\beta$-cells via undiscovered mechanisms.

\begin{tabular}{|c|c|c|c|c|c|}
\hline Plant source & Family & Isolated compound/s & Experimental model & Mode of action & Reference \\
\hline $\begin{array}{l}\text { Aegle marmelos } \\
\text { Correa.-stem bark }\end{array}$ & Rutaceae & $\begin{array}{c}\text { Umbelliferone } \beta \text {-D- } \\
\text { galactopyranoside (18) } \\
\text { (Figure 6) }\end{array}$ & $\begin{array}{c}\text { Wistar rats with DM } \\
\text { induced by STZ }(60 \mathrm{mg} / \\
\text { kg, i.p. })\end{array}$ & $\begin{array}{l}\text { Improvement of } \\
\text { plasma insulin level }\end{array}$ & [123] \\
\hline Centella asiatica $\mathrm{L}$. & Apiaceae & Asiatic acid (16) (Figure 5) & GK rats with T2DM & $\begin{array}{c}\text { Reduction of islet } \\
\text { fibrosis } \\
\text { Reversal of } \\
\text { overexpressed } \\
\text { fibronectin; a key } \\
\text { protein related to islet } \\
\text { fibrosis }\end{array}$ & {$[124]$} \\
\hline Crocus sativus L.-flower & Iridaceae & Saffron (19) (Figure 6) & RIN-5F cells & $\begin{array}{l}\text { Stimulation of insulin } \\
\text { release }\end{array}$ & {$[125]$} \\
\hline $\begin{array}{l}\text { Dendrobium } \\
\text { huoshanense C.Z. Tang } \\
\text { and S.J. Cheng }\end{array}$ & Celastraceae & Polysaccharide & $\begin{array}{c}\text { C57BL/6 mice with DM } \\
\text { induced by HFD followed } \\
\text { by STZ (100 mg/kg, i.p.) }\end{array}$ & $\begin{array}{c}\text { Increase in } \beta \text {-cell mass } \\
\text { Improvement of } \\
\text { HOMA- } \beta\end{array}$ & [126] \\
\hline Dioscorea species & Dioscoreaceae & $\begin{array}{l}\text { Diosgenin (20) (Figure 6) (a } \\
\text { phytosteroid sapogenin) }\end{array}$ & $\begin{array}{c}\text { Albino rats with DM } \\
\text { induced by STZ (40 mg/ } \\
\text { kg, i.p.) }\end{array}$ & $\begin{array}{c}\text { Regeneration of } \\
\beta \text {-cells }\end{array}$ & {$[127]$} \\
\hline $\begin{array}{l}\text { Enicostemma species } \\
\text { Multiple edible plants }\end{array}$ & Gentianaceae & $\begin{array}{l}\text { Swertiamarin (21) (Figure 6) } \\
\text { (secoiridoid glycoside) } \\
\text { quercetin (22) (Figure 6) } \\
\text { (flavanoid) in combination }\end{array}$ & $\begin{array}{c}\text { Albino rats with DM } \\
\text { induced by STZ }(50 \mathrm{mg} / \\
\mathrm{kg} \text {, i.p.) }\end{array}$ & $\begin{array}{l}\text { Regeneration of } \\
\text { pancreatic islets }\end{array}$ & [128] \\
\hline $\begin{array}{l}\text { Hyoscyamus albus } \\
\text { L.--seeds }\end{array}$ & Solanaceae & $\begin{array}{c}\text { Calystegines } \\
\text { (polyhydroxylated alkaloids } \\
\text { and imino-sugars) }\end{array}$ & $\begin{array}{c}\text { Albino rats with DM } \\
\text { induced by STZ }(130 \mathrm{mg} / \\
\text { kg, i.p.) }\end{array}$ & $\begin{array}{c}\text { Regeneration of } \\
\beta \text {-cells }\end{array}$ & [129] \\
\hline Momordica charantia L. & Cucurbitaceae & Genistein (23) (Figure 6) & $\begin{array}{c}\text { Wistar rats with DM } \\
\text { induced by HFD followed } \\
\text { by STZ ( } 40 \mathrm{mg} / \mathrm{kg} \text {, i.p.) }\end{array}$ & $\begin{array}{c}\text { Regeneration of } \\
\beta \text {-cells }\end{array}$ & [103] \\
\hline Multiple plants & NA & $\begin{array}{l}\text { Morin (24) (Figure 7) } \\
\quad \text { (flavonoid) }\end{array}$ & $\begin{array}{c}\text { Albino rats with DM } \\
\text { induced by STZ }(50 \mathrm{mg} / \\
\mathrm{kg} \text {, i.p.) }\end{array}$ & $\begin{array}{l}\text { Preservation of the } \\
\text { normal histological } \\
\text { appearance of } \\
\text { pancreatic islets } \\
\text { Preservation of } \\
\text { insulin-positive } \beta \text {-cells }\end{array}$ & {$[130]$} \\
\hline Multiple plants & NA & $\begin{array}{c}\text { Berberine (25) (Figure 7) } \\
\text { (alkaloid) }\end{array}$ & $\begin{array}{c}\text { Wistar rats with DM } \\
\text { induced by STZ }(35 \mathrm{mg} / \\
\mathrm{kg}, \text { i.p. })\end{array}$ & $\begin{array}{c}\text { Increase in insulin } \\
\text { expression } \\
\text { Regeneration of } \\
\beta \text {-cells } \\
\text { Decrease in MDA and } \\
\text { increase in SOD }\end{array}$ & {$[131]$} \\
\hline Nigella sativa L. & Ranunculaceae & $\begin{array}{l}\text { Thymoquinone (26) } \\
\text { (Figure 7) }\end{array}$ & $\begin{array}{c}\text { Wistar rats with DM } \\
\text { induced by STZ ( } 45 \mathrm{mg} \text { / } \\
\text { kg, i.p.) }\end{array}$ & $\begin{array}{l}\text { Improvement of the } \\
\text { morphology of the } \\
\text { pancreas }\end{array}$ & [132] \\
\hline $\begin{array}{l}\text { Nymphaea stellate } \\
\text { Willd._chloroform } \\
\text { extract of flower }\end{array}$ & Nymphaeaceae & $\begin{array}{c}\text { Nymphayol (27) (Figure 7) (A } \\
\text { sterol) }\end{array}$ & $\begin{array}{c}\text { Wistar rats with DM } \\
\text { induced by STZ }(55 \mathrm{mg} / \\
\mathrm{kg} \text {, i.p. })\end{array}$ & $\begin{array}{l}\text { Increase in the } \\
\text { number of } \beta \text {-cell mass } \\
\text { Increase in islet-like } \\
\text { cell clusters in the } \\
\text { islets of Langerhans }\end{array}$ & {$[133]$} \\
\hline $\begin{array}{l}\text { Protorhus longifolia } \\
\text { (Bernh.) Engl. }\end{array}$ & Anacardiaceae & $\begin{array}{l}\text { Lanosteryl triterpene, methyl- } \\
3 \beta \text {-hydroxylanosta-9,24-dien- } \\
\text { 21-oate }\end{array}$ & $\begin{array}{l}\text { Sprague-Dawley rats } \\
\text { induced with DM by } \\
\text { HFD followed by STZ } \\
\text { (30 mg/kg, i.p.) }\end{array}$ & $\begin{array}{c}\text { Reduction of oxidative } \\
\text { stress and } \\
\text { inflammation } \\
\text { Improvement of } \\
\text { pancreatic structure }\end{array}$ & {$[134]$} \\
\hline
\end{tabular}


TABLE 3: Continued.

\begin{tabular}{|c|c|c|c|c|c|}
\hline Plant source & Family & Isolated compound/s & Experimental model & Mode of action & Reference \\
\hline Rosa canina L.-fruits & Rosaceae & Oligosaccharide & $\begin{array}{c}\text { Wistar rats with DM } \\
\text { induced by STZ }(60 \mathrm{mg} / \\
\text { kg, i.p.) }\end{array}$ & $\begin{array}{l}\text { Improvement of the } \\
\text { structure of pancreatic } \\
\beta \text {-cells and tissues } \\
\text { Increase expression of } \\
\text { Ngn3, Nkx6.1, and } \\
\text { insulin }\end{array}$ & [135] \\
\hline $\begin{array}{l}\text { Solanum torvum } \\
\text { Sw.-fruit }\end{array}$ & Solanaceae & Methyl caffeate (28) (Figure 7) & $\begin{array}{c}\text { Albino rats with DM } \\
\text { induced by STZ }(55 \mathrm{mg} / \\
\text { kg, i.p.) }\end{array}$ & $\begin{array}{c}\text { Regeneration of } \\
\beta \text {-cells }\end{array}$ & [136] \\
\hline $\begin{array}{l}\text { Terminalia bellirica } \\
\text { (Gaertn.) Roxb.- - fruit } \\
\text { rind }\end{array}$ & Combretaceae & Gallic acid (29) (Figure 7) & $\begin{array}{c}\text { Albino rats with DM } \\
\text { induced by STZ }(50 \mathrm{mg} / \\
\text { kg, i.p.) }\end{array}$ & $\begin{array}{c}\text { Regeneration of } \\
\beta \text {-cells }\end{array}$ & [137] \\
\hline Vitex negundo (Linn.) & Verbenaceae & $\begin{array}{l}\text { 20-OH ecdysone (33) } \\
\text { (Figure } 7)\end{array}$ & $\begin{array}{c}\text { Albino rats with DM } \\
\text { induced by STZ ( } 45 \mathrm{mg} \text { / } \\
\text { kg, i.p.) }\end{array}$ & $\begin{array}{l}\text { Regeneration of } \\
\text { pancreatic islets }\end{array}$ & [138] \\
\hline
\end{tabular}

DM, diabetes mellitus; STZ, streptozotocin; i.p., intraperitoneal; HFD, high-fat diet; homeostatic model assessment- $\beta$-cell function HOMA- $\beta$; malondialdehyde, MDA; superoxide dismutase, SOD; neurogenin 3, Ngn3; natural killer cell transcription factor-related, gene family 6, locus 1, Nkx6.1; NA, not applicable.<smiles>O=c1ccc2ccc(O[C@@H]3O[C@H](CO)[C@@H](O)[C@H](O)[C@H]3O)cc2o1</smiles>

(a)

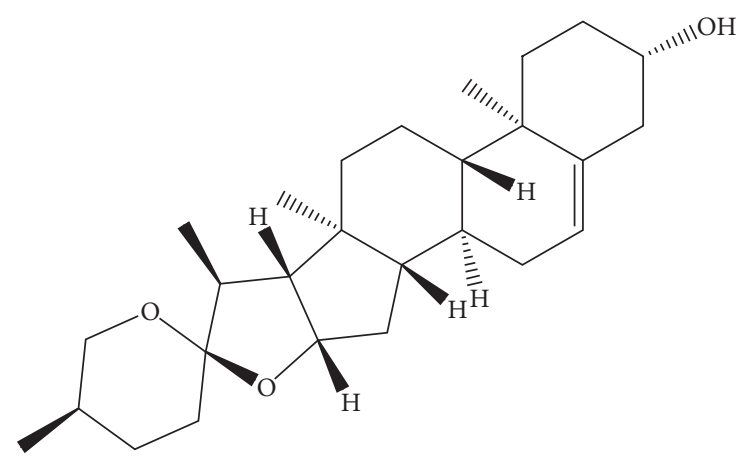

(c)<smiles>O=c1c(O)c(-c2ccc(O)c(O)c2)oc2cc(O)cc(O)c12</smiles>

(e)

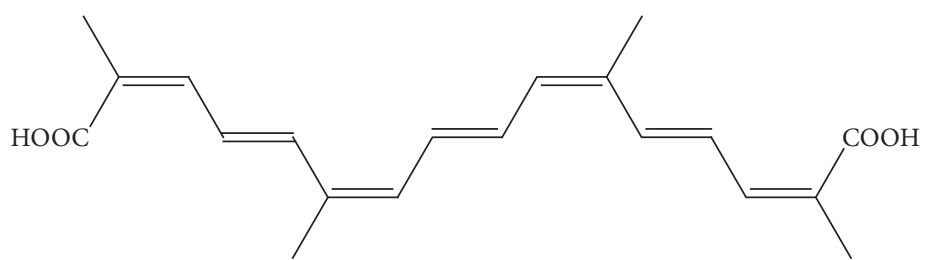

(b)<smiles>C=C[C@H]1[C@H](O[C@@H]2O[C@H](CO)[C@@H](O)[C@H](O)[C@H]2O)OC=C2C(=O)OCC[C@]21O</smiles>

(d)<smiles>O=c1c(-c2ccc(O)cc2)coc2cc(O)cc(O)c12</smiles>

Figure 6: Structures of metabolites (a) umbelliferone beta-D-galactopyranoside (18), (b) saffron (19), (c) diosgenin (20), (d) swertiamarin (21), (e) quercetin (22), and (f) genistein (23) isolated from medicinal plants targeting $\beta$-cells. 
<smiles>O=c1c(O)c(-c2ccc(O)cc2O)oc2cc(O)cc(O)c12</smiles>

(a)

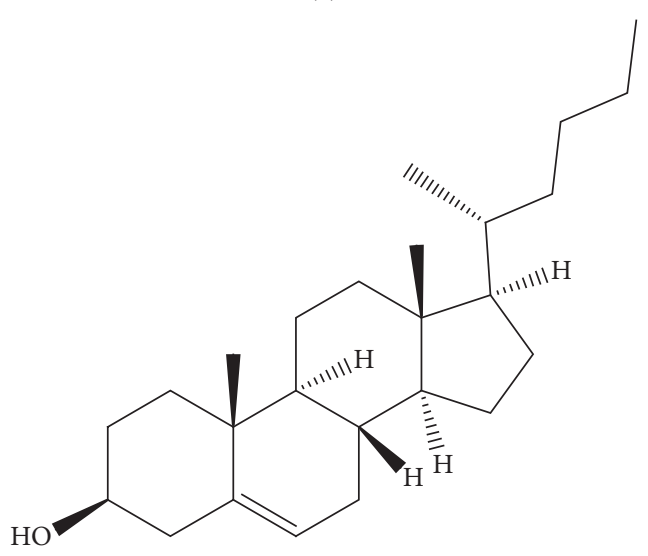

(d)<smiles>COc1ccc2cc3[n+](cc2c1OC)CCc1cc2c(cc1-3)OCO2</smiles>

(b)<smiles>COC(=O)/C=C/c1ccc(O)c(O)c1</smiles>

(e)<smiles>CC1=CC(=O)C(C(C)C)=CC1=O</smiles>

(c)<smiles>O=C(O)c1cc(O)c(O)c(O)c1</smiles>

(f)

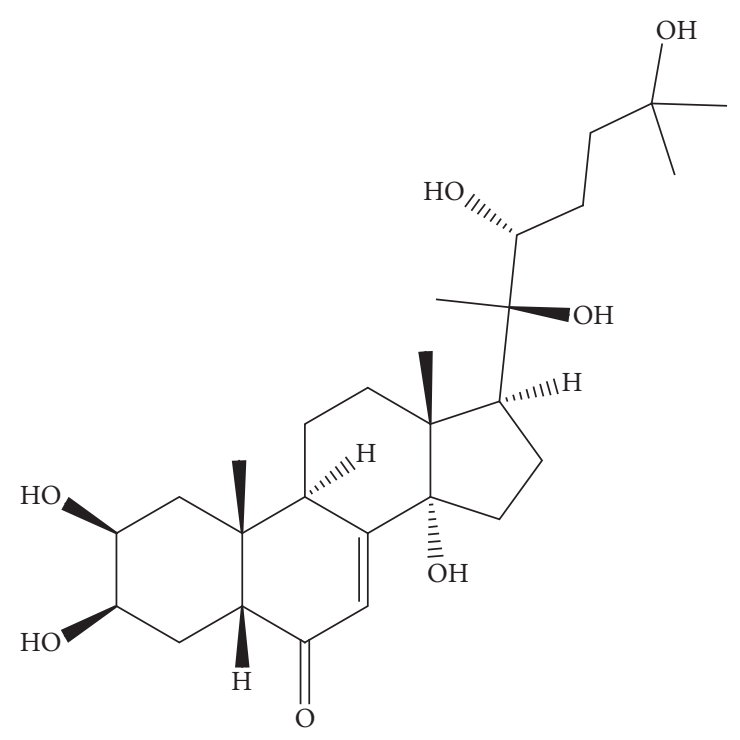

(g)

FIGURE 7: Structures of metabolites (a) morin (24), (b) berberine (25), (c) thymoquinone (26), (d) nymphayol (27), (e) methyl caffeate (28), (f) gallic acid (29), and (g) 20-hydroxyl ecdysone (30) isolated from medicinal plants targeting $\beta$-cells. 


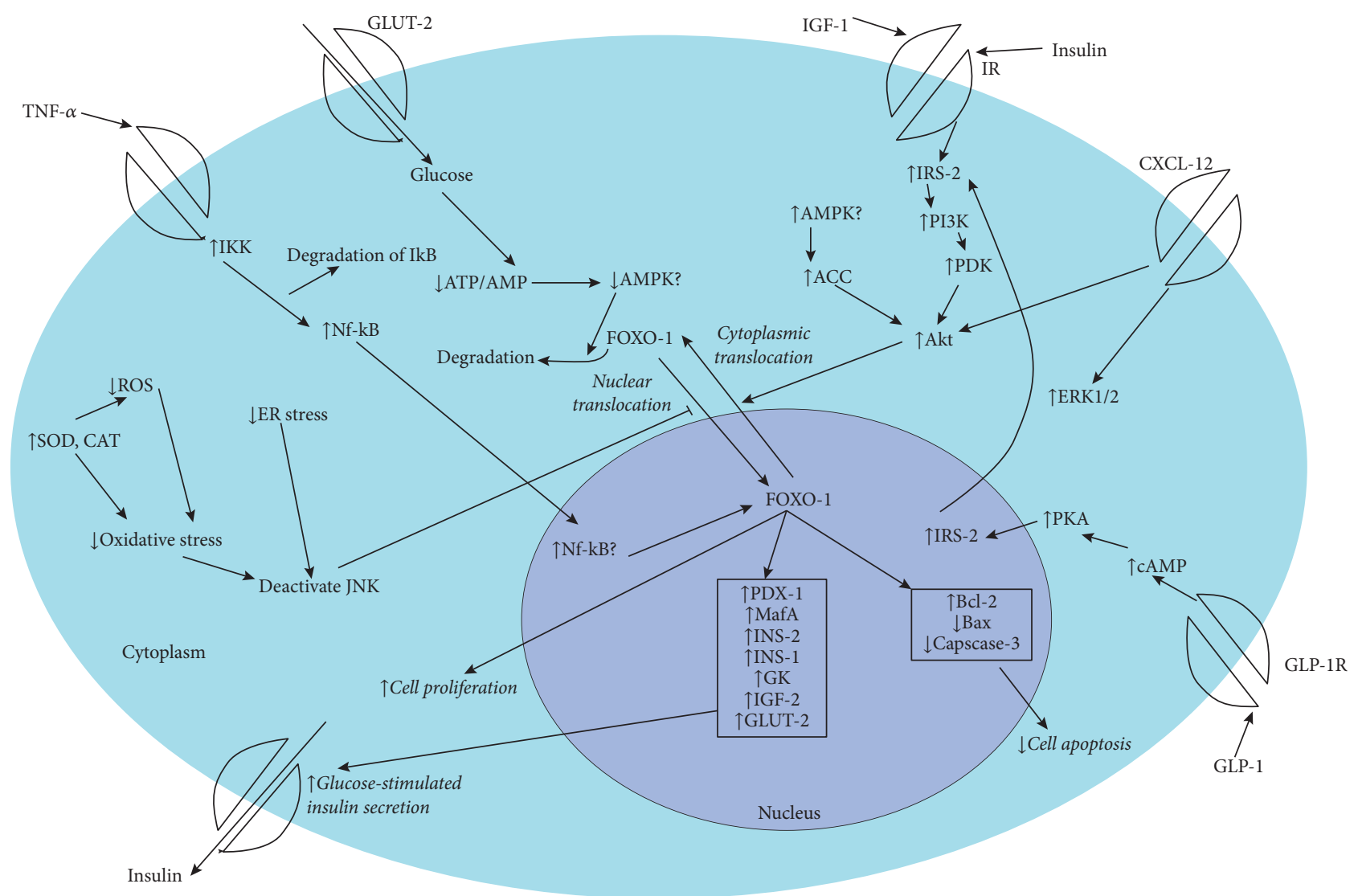

FIGURE 8: Summary of mechanisms by which natural products improve $\beta$-cell function and regeneration. TNF- $\alpha$, tumor necrosis factor- $\alpha$; NF- $\kappa$ B, nuclear factor $\kappa \mathrm{B}$; IkB, inhibitor of NF- $\kappa$ B; IKK, I $\kappa$ B kinase; ATP, adenosine triphosphate; AMP, adenosine monophosphate; AMPK, AMP-activated protein kinase; FOXO-1, forkhead box O1; GLUT-2, glucose transporter-2; IGF-1, insulin-like growth factor-1; IR, insulin receptor; IRS-2, insulin receptor substrate-2; PI3K, phosphoinositide 3-kinase; PDK, phosphoinositide-dependent protein kinase; Akt, protein kinase B; ACC, acetyl-CoA carboxylate; CXCL-12, C-X-C motif chemokine 12; ERK 1/2, Extracellular signal-regulated protein kinase 1/2; PKA, protein kinase A; cAMP, cyclic AMP; GLP-1R, Glucagon-like peptide-1 receptor; SOD, superoxide dismutase; CAT, catalase; ROS, reactive oxygen species; PDX-1, pancreatic duodenal homeobox-1; MafA, v-maf musculoaponeurotic fibrosarcoma oncogene family protein A; INS-1, insulin-1; INS-2, insulin-2; GK, glucokinase; IGF-2, insulin-like growth fator-2; Bcl-2, B-cell lymphoma-2; Bax, Bcl2-associated X, caspase-3, cysteinyl aspartate specific proteinase-3. 
<smiles>OCCc1ccc(O)cc1CO[C@@H]1O[C@H](CO)[C@@H](O)[C@H](O)[C@H]1O</smiles>

(a)<smiles>O=C(O)C=Cc1ccc2noc(-c3ccccc3)c2c1</smiles>

(c)<smiles>O=c1c(O)c(-c2ccc(O)cc2)oc2c(O)c(O)cc(O)c12</smiles>

(e)<smiles>C/C=C1\[C@H](O[C@@H]2O[C@H](CO)[C@@H](O)[C@H](O)[C@H]2O)OC=C(C(=O)OC)[C@H]1CC(=O)OCCc1ccc(O)c(O)c1</smiles>

(b)<smiles>Nc1nc(N)c2ccccc2n1</smiles>

(d)<smiles>COc1cc2oc(-c3ccc(O)cc3)cc(=O)c2c(O)c1O</smiles>

(f)

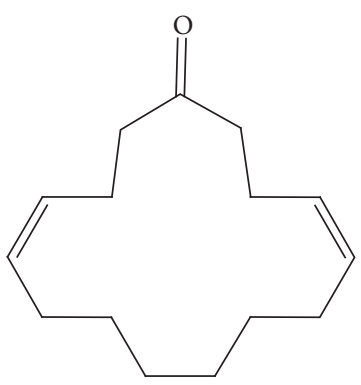

(g)

Figure 9: Compounds targeting $\beta$-cells as evidenced by SAR studies: (a) p-tyrosol (31), (b) oleuropein (32), (c) (E)-3-(3-phenylbenzo[c] isoxazol-5-yl) acrylic acid (33), (d) 2,4-diaminoquinazoline (34), (e) herbacetin (35), (f) sorbifolin (36), and (g) (4Z, 12Z)-cyclopentadeca4,12-dienone (37). 
<smiles>COc1cc(-c2coc3cc(O)c(OC)c(O)c3c2=O)ccc1O</smiles>

(a)<smiles>CC(C)=CCc1c(O)cc(-c2cc3ccc(O)cc3o2)cc1O</smiles>

(b)<smiles>CC(=O)[C@H]1CC[C@]2(O)C3CC=C4C[C@@H](O)CCC4(C)C3C[C@H](O)[C@]12C</smiles>

(e)<smiles>COc1cc2c(c3oc(-c4cc(O)cc(O)c4)cc13)CC=C(C)CO2</smiles>

(c)

(d)<smiles>CC1(C)C=Cc2c(O)cc(-c3cc4ccc(O)cc4o3)cc2O1</smiles>

(g)

FIGURE 10: Structures of metabolites isolated from Morus alba Linne targeting $\beta$-cells as evident by SAR studies. (a) Iristectorigenin A (38), (b) 4-prenylresveratrol (39), (c) moracin H (40), (d) moracin C (41), (e) isoramanone (42), (f) moracin E (43), and (g) moracin D (44).

standardization are major limitations of herbal medicines. Encapsulation of herbal medicines into biocompatible nanomaterials is gaining attention to overcome these limitations. An attempt has been made to nanoencapsulated curcumin in polylactide-co-glycolide. Oral administration of $50 \mathrm{mg} / \mathrm{kg}$ nanocurcumin followed by intraperitoneal injection of STZ $(60 \mathrm{mg} / \mathrm{kg})$ showed $\beta$-cell preservation as evident by TUNEL and H\&E staining of pancreatic tissue, an effect which was not observed in the plain curcumin-treated group [168]. Hence, nanoformulations could be useful in the targeted delivery of bioactive compounds to $\beta$-cells with improved solubility and increased bioavailability.

\section{Conclusions}

A number of single herbal extracts, polyherbal mixtures, and isolated compounds from plant extracts as well as combinations of natural bioactive compounds targeting pancreatic $\beta$-cells have been investigated as preventive/treatment strategies for DM in recent years. Many herbal products reported an improvement of $\beta$-cell function as observed through HOMA- $\beta$. Pancreatic $\beta$-cell regeneration is observed prominently in terms of increase in size and number of pancreatic islets, the number of insulin-secreting cells, and the number of proliferating $\beta$-cells in histopathological/ immunohistochemical studies. Increasing $\beta$-cell mass via the expression of genes/proteins related to antiapoptotic actions and $\beta$-cell neogenesis/proliferation was identified as a mechanism of $\beta$-cell regeneration in some herbal medicines. Increasing glucose-stimulated insulin secretion via activating GLUT-2 receptors and/or increasing intracellular $\mathrm{Ca}^{2+}$ levels was also observed upon treatment with some herbal medicines. Most of the studies suggested that reduction of oxidative stress inflammation by natural products has protective effects on $\beta$-cells. Furthermore, the herbal medicines acted on various insulin signaling pathways by regulating the expression of different receptors and transcriptional factors. However, there are knowledge gaps and unexplored avenues on mechanisms of action of herbal medicines on pancreatic $\beta$-cells, their SAR, and toxicities 
which should be further investigated in order to develop effective therapies against the management of DM.

\section{Data Availability}

No data were used to support this study.

\section{Conflicts of Interest}

The authors declare that there are no conflicts.

\section{Acknowledgments}

The review was written as a proposed activity related to the research project that has been funded by the World Bank under the Accelerating Higher Education Expansion and Development-AHEAD project (AHEAD/DOR STEM-15), Sri Lanka.

\section{References}

[1] American Diabetes Association, "Classification and diagnosis of diabetes: standards of medical care in diabetes," Diabetes Care, vol. 42, no. 1, pp. S13-S28, 2019.

[2] International Diabetes Federation, IDF Diabetes Atlas, International Diabetes Federation, Brussels, Belgium, 9th edition, 2019.

[3] World Health Organization, Noncommunicable Diseases Country Profiles 2018, World Health Organization, 2018.

[4] C. C. Wang and A. C. Shah, Medical Management of Type 1 Diabetes, American Diabetes Association, 7th edition, 2017.

[5] G. Da Silva Xavier, "The cells of the islets of Langerhans," Journal of Clinical Medicine, vol. 7, no. 3, p. 54, 2018.

[6] K. E. Barrett, S. M. Barman, H. L. Brooks, and J. Yuan, Ganong's Review of Medical Physiology, McGraw-Hill Education, New York, NY, USA, 26th edition, 2019.

[7] J. Ilonen, J. Lempainen, and R. Veijola, "The heterogeneous pathogenesis of type 1 diabetes mellitus," Nature Reviews Endocrinology, vol. 15, no. 11, pp. 635-650, 2019.

[8] Z. Fu, E. R. Gilbert, and D. Liu, "Regulation of insulin synthesis and secretion and pancreatic beta-cell dysfunction in diabetes," Current Diabetes Reviews, vol. 9, no. 1, pp. 25-53, 2013.

[9] E. Cersosimo, C. Triplitt, C. Solis-Herrera, J. M. Lawrence, and A. D. Ralph, "Pathogenesis of type 2 diabetes mellitus," in Endotext, K. R. Feingold, B. Anawalt, and A. Boyce, Eds., MDText.com, Inc, South Dartmouth, MA, USA, 2018.

[10] C. Chen, C. M. Cohrs, J. Stertmann, R. Bozsak, and S. Speier, "Human beta cell mass and function in diabetes: recent advances in knowledge and technologies to understand disease pathogenesis," Molecular Metabolism, vol. 6, no. 9, pp. 943-957, 2017.

[11] M. L. Campbell-Thompson, T. Heiple, E. Montgomery, L. Zhang, and L. Schneider, "Staining protocols for human pancreatic islets," Journal of Visualized Experiments, vol. 63, no. 63, Article ID e4068, 2012.

[12] J. J. Meier, A. E. Butler, Y. Saisho et al., " $\beta$-cell replication is the primary mechanism subserving the postnatal expansion of $\beta$-cell mass in humans," Diabetes, vol. 57 , no. 6 , pp. 1584-1594, 2008.

[13] S. Madsbad and J. J. Holst, "Assessment of islet alpha- and beta-cell function," in Translational Research Methods in Diabetes, Obesity, and Nonalcoholic Fatty Liver Disease,
A. Krentz, C. Weyer, and M. Hompesch, Eds., Springer, Cham, Switzerland, 2019.

[14] P. Wang, J.-C. Alvarez-Perez, D. P. Felsenfeld et al., "A highthroughput chemical screen reveals that harmine-mediated inhibition of DYRK1A increases human pancreatic beta cell replication," Nature Medicine, vol. 21, no. 4, pp. 383-388, 2015.

[15] W. Shen, B. Taylor, Q. Jin et al., "Inhibition of DYRK1A and GSK3B induces human $\beta$-cell proliferation," Nature Communications, vol. 6, no. 1, Article ID 8372, 2015.

[16] N. Ben-Othman, A. Vieira, M. Courtney et al., "Long-term GABA administration induces alpha cell-mediated beta-like cell neogenesis," Cell, vol. 168, no. 1-2, pp. 73.e11-85.e11, 2017.

[17] J. Li, T. Casteels, T. Frogne et al., "Artemisinins target GABAA receptor signaling and impair $\alpha$ cell identity," Cell, vol. 168, no. 1-2, pp. 86.e15-100.e15, 2017.

[18] M. Hebrok, "Generating $\beta$-cells from stem cells-the story so far," Cold Spring Harbor Perspectives in Medicine, vol. 2, no. 6, Article ID a007674, 2012.

[19] V. A. Salunkhe, R. Veluthakal, S. E. Kahn, and D. C. Thurmond, "Novel approaches to restore beta cell function in prediabetes and type 2 diabetes," Diabetologia, vol. 61, no. 9, pp. 1895-1901, 2018.

[20] A. Chaudhury, C. Duvoor, V. S. Reddy Dendi et al., "Clinical review of antidiabetic drugs: implications for type 2 diabetes mellitus management," Frontiers in Endocrinology, vol. 8, p. 6, 2017.

[21] R. A. Motlagh, S. Mohebbi, M. Moslemi et al., "Pancreatic $\beta$-cell regeneration: from molecular mechanisms to therapy," Journal of Cellular Biochemistry, vol. 120, no. 9, pp. 1418914200, 2019.

[22] Y. S. Oh, "Plant-derived compounds targeting pancreatic beta cells for the treatment of diabetes," Evidence-based Complementary and Alternative Medicine: eCAM, vol. 2015, Article ID 629863, 12 pages, 2015.

[23] D. K. Semwal, A. Kumar, S. Aswal, A. Chauhan, and R. B. Semwal, "Protective and therapeutic effects of natural products against diabetes mellitus via regenerating pancreatic $\beta$--cells and restoring their dysfunction," Phytotherapy Research, vol. 35, no. 3, pp. 1218-1229, 2021.

[24] A. Ghorbani, R. Rashidi, and R. Shafiee-Nick, "Flavonoids for preserving pancreatic beta cell survival and function: a mechanistic review," Biomedicine \& Pharmacotherapy, vol. 111, pp. 947-957, 2019.

[25] S. Aggarwal, G. Shailendra, D. M. Ribnicky, D. Burk, N. Karki, and M. S. Qingxia Wang, "An extract of Artemisia dracunculus L. stimulates insulin secretion from $\beta$-cells, activates AMPK and suppresses inflammation," Journal of Ethnopharmacology, vol. 170, pp. 98-105, 2015.

[26] I. Leclerc and G. A. Rutter, "AMP-activated protein kinase: a new beta-cell glucose sensor? regulation by amino acids and calcium ions," Diabetes, vol. 53, no. 3, pp. S67-S74, 2004.

[27] A. Fu, C. E. Eberhard, and R. A. Screaton, "Role of AMPK in pancreatic beta cell function," Molecular and Cellular Endocrinology, vol. 366, no. 2, pp. 127-134, 2013.

[28] Y. Cai, Q. Wang, Z. Ling et al., "Akt activation protects pancreatic beta cells from AMPK-mediated death through stimulation of mTOR," Biochemical Pharmacology, vol. 75, no. 10, pp. 1981-1993, 2008.

[29] M. Đorđević, N. Grdović, M. Mihailović et al., "Centaurium erythraea extract improves survival and functionality of pancreatic beta-cells in diabetes through multiple routes of 
action," Journal of Ethnopharmacology, vol. 242, Article ID 112043, 2019.

[30] X. Huang, G. Liu, J. Guo, and Z. Su, "The PI3K/AKT pathway in obesity and type 2 diabetes," International Journal of Biological Sciences, vol. 14, no. 11, pp. 1483-1496, 2018.

[31] M. Đorđević, M. Mihailović, J. Arambašić Jovanović et al., "Centaurium erythraea methanol extract protects red blood cells from oxidative damage in streptozotocin-induced diabetic rats," Journal of Ethnopharmacology, vol. 202, pp. 172-183, 2017.

[32] A. E. Sharp-Tawfik, A. M. Coiner, C. B. MarElia, M. Kazantzis, C. Zhang, and B. R. Burkhardt, "Compositional analysis and biological characterization of Cornus officinalis on human 1.1B4 pancreatic $\beta$-cells," Molecular and Cellular Endocrinology, vol. 494, Article ID 110491, 2019.

[33] M. P. Keller, P. K. Paul, M. E. Rabaglia et al., "The transcription factor Nfatc2 regulates $\beta$-cell proliferation and genes associated with type 2 diabetes in mouse and human islets," PLoS Genetics, vol. 12, no. 12, Article ID e1006466, 2016.

[34] Y. Zhu, Q. Liu, Z. Zhou, and Y. Ikeda, “PDX1, neurogenin-3, and MAFA: critical transcription regulators for beta cell development and regeneration," Stem Cell Research \& Therapy, vol. 8, no. 1, p. 240, 2017.

[35] X.-L. Yin, B.-Q. Xu, and Y.-Q. Zhang, "Gynura divaricata rich in 3,5-/4, 5-dicaffeoylquinic acid and chlorogenic acid reduces islet cell apoptosis and improves pancreatic function in type 2 diabetic mice," Nutrition \& Metabolism, vol. 15, no. 1 , p. 73, 2018.

[36] S. S. Pillai and S. Mini, "Attenuation of high glucose induced apoptotic and inflammatory signaling pathways in RIN-m5F pancreatic $\beta$-cell lines by Hibiscus rosa sinensis L. petals and its phytoconstituents," Journal of Ethnopharmacology, vol. 227, pp. 8-17, 2018.

[37] M. Mihailović, J. Arambašić Jovanović, A. Uskoković et al., "Protective effects of the mushroom lactarius deterrimus extract on systemic oxidative stress and pancreatic islets in streptozotocin-induced diabetic rats," Journal of Diabetes Research, vol. 2015, Article ID 576726, 10 pages, 2015.

[38] C.-D. Sun, B. Zhang, J.-K. Zhang et al., "Cyanidin-3-glucoside-rich extract from Chinese bayberry fruit protects pancreatic $\beta$-cells and ameliorates hyperglycemia in streptozotocin-induced diabetic mice," Journal of Medicinal Food, vol. 15, no. 3, pp. 288-298, 2012.

[39] E.-Y. Park, H.-J. Kim, Y.-K. Kim et al., "Increase in insulin secretion induced by Panax ginseng berry extracts contributes to the amelioration of hyperglycemia in streptozotocininduced diabetic mice," Journal of Ginseng Research, vol. 36, no. 2, pp. 153-160, 2012.

[40] S. S. Sole and B. P. Srinivasan, "Aqueous extract of tamarind seeds selectively increases glucose transporter-2, glucose transporter-4, and islets' intracellular calcium levels and stimulates $\beta$-cell proliferation resulting in improved glucose homeostasis in rats with streptozotocin-induced diabetes mellitus," Nutrition Research, vol. 32, no. 8, pp. 626-636, 2012.

[41] P. S. Tabatabaie and R. Yazdanparast, "Teucrium polium extract reverses symptoms of streptozotocin-induced diabetes in rats via rebalancing the Pdx1 and FoxO1 expressions," Biomedicine \& Pharmacotherapy, vol. 93, pp. 1033-1039, 2017.

[42] M. E. Cam, A. N. Hazar-Yavuz, S. Yildiz et al., "The methanolic extract of Thymus praecox subsp. skorpilii var. skorpilii restores glucose homeostasis, ameliorates insulin resistance and improves pancreatic $\beta$-cell function on streptozotocin/nicotinamide-induced type 2 diabetic rats," Journal of Ethnopharmacology, vol. 231, pp. 29-38, 2019.

[43] A. Domingues, A. Sartori, M. A. Golim et al., "Prevention of experimental diabetes by Uncaria tomentosa extract: Th2 polarization, regulatory T cell preservation or both?" Journal of Ethnopharmacology, vol. 137, no. 1, pp. 635-642, 2011.

[44] A. Arya, M. M. Jamil Al-Obaidi, R. B. Karim et al., "Extract of Woodfordia fruticosa flowers ameliorates hyperglycemia, oxidative stress and improves $\beta$-cell function in streptozotocin-nicotinamide induced diabetic rats," Journal of Ethnopharmacology, vol. 175, pp. 229-240, 2015.

[45] L. Ju, X. Wen, C. Wang et al., "Salidroside, a natural antioxidant, improves $\beta$-cell survival and function via activating AMPK pathway," Frontiers in Pharmacology, vol. 8, p. 749, 2017.

[46] M. Xu, B. Sun, D. Li et al., "Beneficial effects of small molecule oligopeptides isolated from Panax ginseng meyer on pancreatic beta-cell dysfunction and death in diabetic rats," Nutrients, vol. 9, no. 10, 2017.

[47] C. Wang, J. Yao, L. Ju, X. Wen, and L. Shu, "Puerarin ameliorates hyperglycemia in HFD diabetic mice by promoting $\beta$-cell neogenesis via GLP-1R signaling activation," Phytomedicine, vol. 70, Article ID 153222, 2020.

[48] K. Ganesan, K. M. Ramkumar, and B. Xu, "Vitexin restores pancreatic $\beta$-cell function and insulin signaling through Nrf2 and NF- $\kappa \mathrm{B}$ signaling pathways," European Journal of Pharmacology, vol. 888, Article ID 173606, 2020.

[49] Y. Liu, S. Mu, W. Chen et al., "Saponins of Momordica charantia increase insulin secretion in INS-1 pancreatic $\beta$-cells via the PI3K/Akt/FoxO1 signaling pathway," Endocrinología, Diabetes y Nutrición, vol. 68, no. 5, pp. 329-337, 2020.

[50] Z. Zhang, J. Jiang, P. Yu, X. Zeng, J. W. Larrick, and Y. Wang, "Hypoglycemic and beta cell protective effects of andrographolide analogue for diabetes treatment," Journal of Translational Medicine, vol. 7, no. 1, p. 62, 2009.

[51] D. D. Yao, L. Yang, Y. Wang et al., "Geniposide promotes beta-cell regeneration and survival through regulating $\beta$-catenin/TCF7L2 pathway," Cell Death \& Disease, vol. 6, no. 5, Article ID e1746, 2015.

[52] J. Liu, T. He, Q. Lu, J. Shang, H. Sun, and L. Zhang, "Asiatic acid preserves beta cell mass and mitigates hyperglycemia in streptozocin-induced diabetic rats," Diabetes/Metabolism Research and Reviews, vol. 26, no. 6, pp. 448-454, 2010.

[53] Y. Zhang, Z. He, X. Liu et al., "Oral administration of Angelica sinensis polysaccharide protects against pancreatic islets failure in type 2 diabetic mice: pancreatic $\beta$-cell apoptosis inhibition," Journal of Functional Foods, vol. 54, pp. 361-370, 2019.

[54] I. Mathijs, D. A. Da Cunha, E. Himpe et al., "Phenylpropenoic acid glucoside augments pancreatic beta cell mass in high-fat diet-fed mice and protects beta cells from ER stress-induced apoptosis," Molecular Nutrition \& Food Research, vol. 58, no. 10, pp. 1980-1990, 2014.

[55] E. Himpe, D. A. Cunha, I. Song et al., "Phenylpropenoic acid glucoside from rooibos protects pancreatic beta cells against cell death induced by acute injury," PLoS One, vol. 11, no. 6, Article ID e0157604, 2016.

[56] Q.-C. Xing, X. Liu, W. Li, Y.-Z. Chen, and J. Chen, "Sangguayin preparation prevents palmitate-induced apoptosis by suppressing endoplasmic reticulum stress and autophagy in $\mathrm{db} / \mathrm{db}$ mice and MIN6 pancreatic $\beta$-cells," 
Chinese Journal of Natural Medicines, vol. 18, no. 6, pp. 472-480, 2020.

[57] D. S. N. K. Liyanagamage, S. Jayasinghe, A. P. Attanayake, and V. Karunaratne, "Dual mechanisms of a Sri Lankan traditional polyherbal mixture in the improvement of pancreatic beta cell functions and restoration of lipoprotein alterations in streptozotocin induced diabetic rats," Journal of Ethnopharmacology, vol. 267, Article ID 113613, 2021.

[58] G. Kaur, M. Invally, M. K. Khan, and P. Jadhav, "A nutraceutical combination of Cinnamomum cassia \& Nigella sativa for type 1 diabetes mellitus," Journal of Ayurveda and Integrative Medicine, vol. 9, no. 1, pp. 27-37, 2018.

[59] M. Akpaso, I. J. Atangwho, A. Akpantah, V. A. Fischer, A. O. Igiri, and P. E. Ebong, "Effect of combined leaf extracts of Vernonia amygdalina (bitter leaf) and Gongronema latifolium (utazi) on the pancreatic $\beta$-cells of streptozotocininduced diabetic rats," British Journal of Medicine and Medical Research, vol. 1, no. 1, pp. 24-34, 2011.

[60] F. Mahmoud, E. Al-Ozairi, D. Haines et al., "Effect of diabetea tea ${ }^{\mathrm{TM}}$ consumption on inflammatory cytokines and metabolic biomarkers in type 2 diabetes patients," Journal of Ethnopharmacology, vol. 194, pp. 1069-1077, 2016.

[61] A. Asadi, F. Shidfar, M Safari et al., "Efficacy of Melissa officinalis L. (lemon balm) extract on glycemic control and cardiovascular risk factors in individuals with type 2 diabetes: a randomized, double-blind, clinical trial," Phytotherapy Research: PTR, vol. 33, no. 3, pp. 651-659, 2019.

[62] Y.-H. Huang, S.-T. Chen, F.-H. Liu et al., "The efficacy and safety of concentrated herbal extract granules, $\mathrm{YH} 1$, as an add-on medication in poorly controlled type 2 diabetes: a randomized, double-blind, placebo-controlled pilot trial," PLoS One, vol. 14, no. 8, Article ID e0221199, 2019.

[63] A. Boye, D. O. Acheampong, E. O. Gyamerah et al., "Glucose lowering and pancreato-protective effects of Abrus Precatorius (L.) leaf extract in normoglycemic and STZ/nicotinamide-induced diabetic rats," Journal of Ethnopharmacology, vol. 258, Article ID 112918, 2020.

[64] R. T. Narendhirakannan and S. Subramanian, "Biochemical evaluation of the protective effect of Aegle marmelos (L.), Corr. leaf extract on tissue antioxidant defense system and histological changes of pancreatic beta-cells in streptozotocin-induced diabetic rats," Drug and Chemical Toxicology, vol. 33, no. 2, pp. 120-130, 2010.

[65] G. R. Gandhi, S. Ignacimuthu, and M. G. Paulraj, "Hypoglycemic and $\beta$-cells regenerative effects of Aegle marmelos (L.) Corr. bark extract in streptozotocin-induced diabetic rats," Food and Chemical Toxicology, vol. 50, no. 5, pp. 1667-1674, 2012.

[66] A. Noor, S. Gunasekaran, and M. A. Vijayalakshmi, "Improvement of insulin secretion and pancreatic $\beta$-cell function in streptozotocin-induced diabetic rats treated with Aloe vera extract," Pharmacognosy Research, vol. 9, no. 1, pp. S99-S104, 2017.

[67] R. M. Hafizur, N. Kabir, and S. Chishti, "Asparagus officinalis extract controls blood glucose by improving insulin secretion and $\beta$-cell function in streptozotocin-induced type 2 diabetic rats," British Journal of Nutrition, vol. 108, no. 9, pp. 1586-1595, 2012.

[68] W. H. El-Tantawy, N. D. Soliman, D. El-naggar, and A. Shafei, "Investigation of antidiabetic action of Antidesma bunius extract in type 1 diabetes," Archives of Physiology and Biochemistry, vol. 121, no. 3, pp. 116-122, 2015.
[69] Y.-D. Jeon, S.-H. Kang, K.-H. Moon et al., "The effect of aronia berry on type 1 diabetes in vivo and in vitro," Journal of Medicinal Food, vol. 21, no. 3, pp. 244-253, 2018.

[70] M. Indrowati, R. Pratiwi, Rumiyati, and P. Astuti, "Levels of blood glucose and insulin expression of beta-cells in streptozotocin-induced diabetic rats treated with ethanolic extract of Artocarpus altilis leaves and GABA," Pakistan Journal of Biological Sciences: PJBS, vol. 20, no. 1, pp. 28-35, 2017.

[71] X. Yin, Y. Huang, D.-W. Jung et al., "Anti-diabetic effect of Aster sphathulifolius in C57BL/KsJ-db/db mice," Journal of Medicinal Food, vol. 18, no. 9, pp. 987-998, 2015.

[72] N. L. Lartey, H. Asare-Anane, E. K. Ofori et al., "Antidiabetic activity of aqueous stem bark extract of Annickia polycarpa in alloxan-induced diabetic mice," Journal of Traditional and Complementary Medicine, vol. 11, no. 2, pp. 109-116, 2021.

[73] M. Bhat, S. K. Kothiwale, A. R. Tirmale, S. Y. Bhargava, and B. N. Joshi, "Antidiabetic properties of Azardiracta indica and Bougainvillea spectabilis: in vivo studies in murine diabetes model," Evidence-Based Complementary and Alternative Medicine: eCAM, vol. 2011, Article ID 561625, 9 pages, 2011.

[74] N. K. Choudhary, S. Sharma, A. K. Jha, M. S. Karchuli, and J. Dwivedi, "Antioxidant potential and protection of pancreatic $\beta$-cells by Calotropis gigantea in streptozocin induced diabetic rats," Journal of Complementary \& Integrative Medicine, vol. 9, p. 8, 2012.

[75] N. Irshad, M. S. Akhtar, S. Bashir et al., "Hypoglycaemic effects of methanolic extract of Canscora decussata (Schult) whole-plant in normal and alloxan-induced diabetic rabbits," Pakistan Journal of Pharmaceutical Sciences, vol. 28, no. 1, pp. 167-174, 2015.

[76] S. Sasidharan, V. Sumathi, N. R. Jegathambigai, and L. Y. Latha, "Antihyperglycaemic effects of ethanol extracts of Carica papaya and Pandanus amaryfollius leaf in streptozotocin-induced diabetic mice," Natural Product Research, vol. 25, no. 20, pp. 1982-1987, 2011.

[77] L. Verma, P. K. Singour, P. K. Chaurasiya, H. Rajak, R. S. Pawar, and U. K. Patil, "Effect of ethanolic extract of Cassia occidentalis Linn. for the management of alloxaninduced diabetic rats," Pharmacognosy Research, vol. 2, no. 3, pp. 132-137, 2010.

[78] J. Gorelick, A. Kitron, S. Pen, T. Rosenzweig, and Z. Madar, "Anti-diabetic activity of Chiliadenus iphionoides," Journal of Ethnopharmacology, vol. 137, no. 3, pp. 1245-1249, 2011.

[79] N. Sebbagh, C. Cruciani-Guglielmacci, F. Ouali et al., "Comparative effects of Citrullus colocynthis, sunflower and olive oil-enriched diet in streptozotocin-induced diabetes in rats," Diabetes \& Metabolism, vol. 35, no. 3, pp. 178-184, 2009.

[80] P. R. Verma, P. R. Itankar, and S. K. Arora, "Evaluation of antidiabetic antihyperlipidemic and pancreatic regeneration, potential of aerial parts of Clitoria ternatea," Revista Brasileira de Farmacognosia, vol. 23, no. 5, pp. 819-829, 2013.

[81] E. Bahar, K.-M. Akter, G.-H. Lee et al., " $\beta$-Cell protection and antidiabetic activities of Crassocephalum crepidioides (Asteraceae) Benth. S. Moore extract against alloxan-induced oxidative stress via regulation of apoptosis and reactive oxygen species (ROS)," BMC Complementary and Alternative Medicine, vol. 17, no. 1, p. 179, 2017.

[82] A. P. Attanayake, K. A. P. W. Jayatilaka, L. K. B. Mudduwa, and C. Pathirana, " $\beta$-cell regenerative potential of selected herbal extracts in alloxan induced diabetic rats," Current 
Drug Discovery Technologies, vol. 16, no. 3, pp. 278-284, 2019.

[83] P. Kalailingam, K. Balasubramanian, B. Kannaian et al., "Isolation and quantification of flavonoids from ethanol extract of Costus igneus rhizome (CiREE) and impact of CiREE on hypoglycaemic, electron microscopic studies of pancreas in streptozotocin (STZ)-induced diabetic rats," Biomedicine \& Preventive Nutrition, vol. 3, no. 3, pp. 285297, 2013.

[84] S. A. Kalekar, R. P. Munshi, and U. M. Thatte, "Do plants mediate their anti-diabetic effects through anti-oxidant and anti-apoptotic actions? an in vitro assay of 3 Indian medicinal plants," BMC Complementary and Alternative Medicine, vol. 13, no. 1, p. 257, 2013.

[85] C. A. Okolo, V. C. Ejere, C. O. Chukwuka, Ezeigbo II, D. D. Nwibo, and A. N. Okorie, "Hexane extract of Dacryodes edulis fruits possesses anti-diabetic and hypolipidaemic potentials in alloxan diabetes of rats," Africa Journal of Traditional Complementary and Alternative Medicine, vol. 13, no. 4, pp. 132-144, 2016.

[86] O. L. Erukainure, O. M. Ijomone, C. I. Chukwuma, X. Xiao, V. F. Salau, and M. S. Islam, "Dacryodes edulis (G. Don) H.J. Lam modulates glucose metabolism, cholinergic activities and Nrf2 expression, while suppressing oxidative stress and dyslipidemia in diabetic rats," Journal of Ethnopharmacology, vol. 255, Article ID 112744, 2020.

[87] F. Qa'dan, E. J. Verspohl, A. Nahrstedt, F. Petereit, and K. Z. Matalka, "Cinchonain Ib isolated from Eriobotrya japonica induces insulin secretion in vitro and in vivo," Journal of Ethnopharmacology, vol. 124, no. 2, pp. 224-227, 2009.

[88] C.-H. Tsai, T.-C. Fang, P.-L. Liao et al., "The powdered root of Eurycoma longifolia jack improves beta-cell number and pancreatic islet performance through pdx1 induction and shows antihyperglycemic activity in $\mathrm{db} / \mathrm{db}$ mice," Nutrients, vol. 12, no. 7, Article ID 2111, 2020.

[89] S. Stephen Irudayaraj, S. Christudas, S. Antony, V. Duraipandiyan, A.-D. Naif Abdullah, and S. Ignacimuthu, "Protective effects of Ficus carica leaves on glucose and lipids levels, carbohydrate metabolism enzymes and $\beta$-cells in type 2 diabetic rats," Pharmaceutical Biology, vol. 55, no. 1, pp. 1074-1081, 2017.

[90] H. Yang, M. Kim, D. Kwon et al., "Anti-diabetic activities of Gastrodia elata blume water extracts are mediated mainly by potentiating glucose-stimulated insulin secretion and increasing $\beta$-cell mass in non-obese type 2 diabetic animals," Nutrients, vol. 8, no. 3, p. 161, 2016.

[91] R. Uzzaman and M. Ghaffar, "Anti-diabetic and hypolipidemic effects of extract from the seed of Gossypium herbaceum L. in alloxan-induced diabetic rabbits," Pakistan Journal of Pharmaceutical Sciences, vol. 30, no. 1, pp. 75-86, 2017.

[92] A. P. Attanayake, K. A. Jayatilaka, C. Pathirana, and L. K. Mudduwa, "Gmelina arborea Roxb. (family: Verbenaceae) extract upregulates the $\beta$-cell regeneration in STZ induced diabetic rats," Journal of Diabetes Research, vol. 2016, Article ID 4513871, 8 pages, 2016.

[93] K. M. Ramkumar, C. Manjula, L. Sankar, S. Suriyanarayanan, and P. Rajaguru, "Potential in vitro antioxidant and protective effects of Gymnema montanum $\mathrm{H}$. on alloxan-induced oxidative damage in pancreatic $\beta$-cells, HIT-T15," Food and Chemical Toxicology, vol. 47, no. 9, pp. 2246-2256, 2009.
[94] A. B. A. Ahmed, A. S. Rao, and M. V. Rao, "In vitro callus and in vivo leaf extract of Gymnema sylvestre stimulate $\beta$-cells regeneration and anti-diabetic activity in Wistar rats," Phytomedicine, vol. 17, no. 13, pp. 1033-1039, 2010.

[95] D. O. Adeyemi and O. S. Adewole, "Hibiscus sabdariffa renews pancreatic $\beta$-cells in experimental type 1 diabetic model rats," Morphologie, vol. 103, no. 341, pp. 80-93, 2019.

[96] A. Akinrinde, T. Koekemoer, M. V. D. Venter, and G. Bradley, "In vitro investigation of potential anti-diabetic activity of the corm extract of Hypoxis argentea Harv. Ex Baker," Acta Pharmaceutica, vol. 68, no. 4, pp. 389-407, 2018.

[97] M. Srujana, R. Ramesh, and L. D. Nanjaiah, “Antidiabetic potential of active fraction obtained from methanolic extract of Ichnocarpus frutescens: a possible herbal remedy," Indian Journal of Pharmacology, vol. 50, no. 5, pp. 251-259, 2018.

[98] M. A. Ibrahim and M. S. Islam, "Butanol fraction of Khaya senegalensis root modulates $\beta$-cell function and ameliorates diabetes-related biochemical parameters in a type 2 diabetes rat model," Journal of Ethnopharmacology, vol. 154, no. 3, pp. 832-838, 2014.

[99] R. R. Mohammed, A. K. Omer, Z. Yener, A. Uyar, and A. K. Ahmed, "Biomedical effects of Laurus nobilis L. leaf extract on vital organs in streptozotocin-induced diabetic rats: experimental research," Annals of Medicine and Surgery, vol. 61, pp. 188-197, 2021.

[100] J. Mawa, M. A. Rahman, M. A. Hashem, and M. Juwel Hosen, "Leea macrophylla root extract upregulates the mRNA expression for antioxidative enzymes and repairs the necrosis of pancreatic $\beta$-cell and kidney tissues in fructose-fed type 2 diabetic rats," Biomedicine \& Pharmacotherapy, vol. 110, pp. 74-84, 2019.

[101] M. Saleem, M. Tanvir, M. F. Akhtar, M Iqbal, and A Saleem, "Antidiabetic potential of Mangifera indica L. Cv. Anwar Ratol leaves: medicinal application of food wastes," Medicina (Kaunas, Lithuania), vol. 55, no. 7, 2019.

[102] R. M. Hafizur, N. Kabir, and S. Chishti, "Modulation of pancreatic $\beta$-cells in neonatally streptozotocin-induced type 2 diabetic rats by the ethanolic extract of Momordica charantia fruit pulp," Natural Product Research, vol. 25, no. 4, pp. 353-367, 2011.

[103] W. Makena, J. O. Hambolu, J. A. Timbuak, U. E. Umana, A. I. Iliya, and N. I. Dibal, "Mormodica charantia L. fruit and Genistein ameliorates type 2 diabetes in rats by preventing lipid accumulation, insulin resistance and enhancing beta cell function," Journal of Diabetes \& Metabolic Disorders, vol. 19, no. 2, 2020.

[104] M. A. Hossain, M. Mostofa, M. A. Awal, E. H. Chowdhury, and M. H. Sikder, "Histomorphological and morphometric studies of the pancreatic islet cells of diabetic rats treated with aqueous extracts of Momordica charantia (karela) fruits," Asian Pacific Journal of Tropical Disease, vol. 4, pp. S698S704, 2014.

[105] A. Abd El Latif, B. E. S. El Bialy, H. D. Mahboub, and M. A. Abd Eldaim, "Moringa oleiferaleaf extract ameliorates alloxan-induced diabetes in rats by regeneration of $\beta$-cells and reduction of pyruvate carboxylase expression," Biochemistry and Cell Biology, vol. 92, no. 5, pp. 413-419, 2014.

[106] N. A. Yusoff, V. Lim, B. Al-Hindi et al., "Nypa fruticans Wurmb. vinegar's aqueous extract stimulates insulin secretion and exerts hepatoprotective effect on STZ-induced diabetic rats," Nutrients, vol. 9, no. 9, 2017.

[107] A. Manzari-Tavakoli, I. Pouraboli, M.-M. Yaghoobi, M. Mehrabani, and S.-M. Mirtadzadini, "Antihyperglycemic, 
antilipid peroxidation, and insulin secretory activities of Otostegia persica shoot extract in streptozotocin-induced diabetic rats and in vitro $\mathrm{C} 187$ pancreatic $\beta$-cells," Pharmaceutical Biology, vol. 51, no. 2, pp. 253-259, 2013.

[108] M. A. Ibrahim, J. D. Habila, N. A. Koorbanally, and M. S. Islam, "Butanol fraction of Parkia biglobosa (Jacq.) G. Don leaves enhance pancreatic $\beta$-cell functions, stimulates insulin secretion and ameliorates other type 2 diabetes-associated complications in rats," Journal of Ethnopharmacology, vol. 183, pp. 103-111, 2016.

[109] H. Ram, N. Jaipal, P. Kumar et al., "Dual inhibition of DPP-4 and cholinesterase enzymes by the phytoconstituents of the ethanolic extract of Prosopis cineraria pods: therapeutic implications for the treatment of diabetes-associated neurological impairments," Current Alzheimer Research, vol. 16, no. 13, pp. 1230-1244, 2019.

[110] H. Taha, A. Arya, A. K. Khan, N. Shahid, M. I. Bin Noordin, and S. Mohan, "Effect of Pseuduvaria macrophylla in attenuating hyperglycemia mediated oxidative stress and inflammatory response in STZ-nicotinamide induced diabetic rats by upregulating insulin secretion and glucose transporter-1, 2 and 4 proteins expression," Journal of Applied Biomedicine, vol. 16, no. 4, pp. 263-273, 2018.

[111] A. P. Attanayake, K. A. P. W. Jayatilaka, C. Pathirana, and L. K. B. Mudduwa, "Antihyperglycaemic, antihyperlipidaemic and $\beta$-cell regenerative effects of Spondias pinnata (Linn. f.) Kurz. bark extract on streptozotocin induced diabetic rats," European Journal of Integrative Medicine, vol. 6, no. 5, pp. 588-596, 2014.

[112] G. Krishnasamy, K. Muthusamy, D. R. Chellappan, and N. Subbiah, "Antidiabetic, antihyperlipidaemic, and antioxidant activity of Syzygium densiflorum fruits in streptozotocin and nicotinamide-induced diabetic rats," Pharmaceutical Biology, vol. 54, no. 9, pp. 1716-1726, 2016.

[113] Y.-L. Wang, Z.-Q. Xiao, S. Liu et al., "Antidiabetic effects of Swertia macrosperma extracts in diabetic rats," Journal of Ethnopharmacology, vol. 150, no. 2, pp. 536-544, 2013.

[114] S. S. Bhadoriya, A. Ganeshpurkar, R. P. S. Bhadoriya, S. K. Sahu, and J. R. Patel, "Antidiabetic potential of polyphenolic-rich fraction of Tamarindus indica seed coat in alloxan-induced diabetic rats," Journal of Basic and Clinical Physiology and Pharmacology, vol. 29, no. 1, pp. 37-45, 2018.

[115] R. Bahramsoltani, M. H. Farzaei, S. Sajadimajd et al., "In vitro and in vivo antidiabetic activity of Tamarix stricta Boiss: role of autophagy," Journal of Ethnopharmacology, vol. 269, Article ID 113692, 2020.

[116] M. Esmaeili, F. Zohari, and H. Sadeghi, "Antioxidant and protective effects of major flavonoids from Teucrium polium on beta-cell destruction in a model of streptozotocin-induced diabetes," Planta Medica, vol. 75, no. 13, pp. 1418-1420, 2009.

[117] M. Rajalakshmi, J. Eliza, C. E. Priya, A. Nirmala, and P. Daisy, "Anti-diabetic properties of Tinospora cordifolia stem extracts on streptozotocin- induced diabetic rats," African Journal of Pharmacy and Pharmacology, vol. 3, no. 5, pp. 171-180, 2009.

[118] Y. Purnomo, D. W. Soeatmadji, S. B. Sumitro, and M. A. Widodo, "Incretin effect of Urena lobata leaves extract on structure and function of rats islet $\beta$-cells," Journal of Traditional and Complementary Medicine, vol. 7, no. 3, pp. 301-306, 2017.

[119] A. Ranjbari, M. A. Azarbayjani, A. Yusof et al., "In vivo and in vitro evaluation of the effects of Urtica dioica and swimming activity on diabetic factors and pancreatic beta cells," BMC Complementary and Alternative Medicine, vol. 16, no. 1, p. 101, 2016.

[120] O. Oche, I. Sani, N. G. Chiaka, N. U. Samuel, and A. Samuel, "Pancreatic islet regeneration and some liver biochemical parameters of leaf extracts of Vitex doniana in normal and streptozotocin-induced diabetic albino rats," Asian Pacific Journal of Tropical Biomedicine, vol. 4, no. 2, pp. 124-130, 2014.

[121] D. Miaffo, F. Ntchapda, T. A. Mahamad, B. Maidadi, and A. Kamanyi, "Hypoglycemic, antidyslipidemic and antioxydant effects of Vitellaria paradoxa barks extract on highfat diet and streptozotocin-induced type 2 diabetes rats," Metabolism Open, vol. 9, Article ID 100071, 2021.

[122] K. Heimes, B. Feistel, and E. J. Verspohl, "Impact of the 5HT3 receptor channel system for insulin secretion and interaction of ginger extracts," European Journal of Pharmacology, vol. 624, no. 1-3, pp. 58-65, 2009.

[123] V. Kumar, D. Ahmed, A. Verma, F. Anwar, M. Ali, and M. Mujeeb, "Umbelliferone $\beta$-D-galactopyranoside from Aegle marmelos (L.) corr. an ethnomedicinal plant with antidiabetic, antihyperlipidemic and antioxidative activity," BMC Complementary and Alternative Medicine, vol. 13, no. 1, p. 273, 2013.

[124] X. Wang, Q. Lu, D.-S. Yu et al., "Asiatic acid mitigates hyperglycemia and reduces islet fibrosis in Goto-Kakizaki rat, a spontaneous type 2 diabetic animal model," Chinese Journal of Natural Medicines, vol. 13, no. 7, pp. 529-534, 2015.

[125] F. Dehghan, F. Hajiaghaalipour, A. Yusof et al., "Saffron with resistance exercise improves diabetic parameters through the GLUT4/AMPK pathway in-vitro and in-vivo," Scientific Reports, vol. 6, no. 1, Article ID 25139, 2016.

[126] H.-Y. Wang, Q.-M. Li, N.-J. Yu et al., "Dendrobium huoshanense polysaccharide regulates hepatic glucose homeostasis and pancreatic $\beta$-cell function in type 2 diabetic mice," Carbohydrate Polymers, vol. 211, pp. 39-48, 2019.

[127] P. Kalailingam, B. Kannaian, E. Tamilmani, and R. Kaliaperumal, "Efficacy of natural diosgenin on cardiovascular risk, insulin secretion, and beta cells in streptozotocin (STZ)-induced diabetic rats," Phytomedicine, vol. 21, no. 10, pp. 1154-1161, 2014.

[128] V. Jaishree and S. Narsimha, "Swertiamarin and quercetin combination ameliorates hyperglycemia, hyperlipidemia and oxidative stress in streptozotocin-induced type 2 diabetes mellitus in wistar rats," Biomedicine \& Pharmacotherapy, vol. 130, Article ID 110561, 2020.

[129] L. Bourebaba, S. Saci, D. Touguit et al., "Evaluation of antidiabetic effect of total calystegines extracted from Hyoscyamus albus," Biomedicine \& Pharmacotherapy, vol. 82, pp. 337-344, 2016.

[130] P. Vanitha, C. Uma, N. Suganya et al., "Modulatory effects of morin on hyperglycemia by attenuating the hepatic key enzymes of carbohydrate metabolism and $\beta$-cell function in streptozotocin-induced diabetic rats," Environmental Toxicology and Pharmacology, vol. 37, no. 1, pp. 326-335, 2014.

[131] J. Zhou, S. Zhou, J. Tang et al., "Protective effect of berberine on beta cells in streptozotocin- and high-carbohydrate/highfat diet-induced diabetic rats," European Journal of Pharmacology, vol. 606, no. 1, pp. 262-268, 2009.

[132] C. Sankaranarayanan and L. Pari, "Thymoquinone ameliorates chemical induced oxidative stress and $\beta$-cell damage in experimental hyperglycemic rats," Chemico-Biological Interactions, vol. 190, no. 2, pp. 148-154, 2011. 
[133] P. Subash-Babu, S. Ignacimuthu, P. Agastian, and B. Varghese, "Partial regeneration of $\beta$-cells in the islets of Langerhans by Nymphayol a sterol isolated from Nymphaea stellata (Willd.) flowers," Bioorganic \& Medicinal Chemistry, vol. 17, no. 7, pp. 2864-2870, 2009.

[134] S. Mabhida, R. Mosa, D. Penduka et al., "A lanosteryl triterpene from Protorhus longifolia improves glucose tolerance and pancreatic beta cell ultrastructure in type 2 diabetic rats," Molecules, vol. 22, no. 8, Article ID 1252, 2017.

[135] M. Rahimi, S. Sajadimajd, Z. Mahdian et al., "Characterization and anti-diabetic effects of the oligosaccharide fraction isolated from Rosa canina in STZ-Induced diabetic rats," Carbohydrate Research, vol. 489, Article ID 107927, 2020.

[136] G. R. Gandhi, S. Ignacimuthu, M. G. Paulraj, and P. Sasikumar, "Antihyperglycemic activity and antidiabetic effect of methyl caffeate isolated from Solanum torvum Swartz. fruit in streptozotocin induced diabetic rats," $E u$ ropean Journal of Pharmacology, vol. 670, no. 2, pp. 623-631, 2011.

[137] R. C. Latha and P. Daisy, "Insulin-secretagogue, antihyperlipidemic and other protective effects of gallic acid isolated from Terminalia bellerica Roxb. in streptozotocininduced diabetic rats," Chemico-Biological Interactions, vol. 189, no. 1, pp. 112-118, 2011.

[138] R. Sundaram, R. Naresh, P. Shanthi, and P. Sachdanandam, "Ameliorative effect of $20-\mathrm{OH}$ ecdysone on streptozotocin induced oxidative stress and $\beta$-cell damage in experimental hyperglycemic rats," Process Biochemistry, vol. 47, no. 12, pp. 2072-2080, 2012.

[139] T. Tomita, "Apoptosis in pancreatic $\beta$-islet cells in type 2 diabetes," Bosnian Journal of Basic Medical Sciences, vol. 16, no. 3, pp. 162-179, 2016.

[140] C. Liu and H. Wu, "From beta cell replacement to beta cell regeneration: implications for antidiabetic therapy," Journal of Diabetes Science and Technology, vol. 8, no. 6, pp. 12211226, 2014.

[141] J.-C. Henquin, "Pathways in beta-cell stimulus-secretion coupling as targets for therapeutic insulin secretagogues," Diabetes, vol. 53, no. 3, pp. S48-S58, 2004.

[142] C. A. Rice-Evans, N. J. Miller, and G. Paganga, "Structureantioxidant activity relationships of flavonoids and phenolic acids," Free Radical Biology and Medicine, vol. 20, no. 7, pp. 933-956, 1996.

[143] B. M. Rezk, G. R. M. M. Haenen, W. J. F. van der Vijgh, and A. Bast, "The antioxidant activity of phloretin: the disclosure of a new antioxidant pharmacophore in flavonoids," Biochemical and Biophysical Research Communications, vol. 295, no. 1, pp. 9-13, 2002.

[144] G. G. Kang, N. Francis, R. Hill, D. Waters, C. Blanchard, and A. B. Santhakumar, "Dietary polyphenols and gene expression in molecular pathways associated with type 2 diabetes mellitus: a review," International Journal of Molecular Sciences, vol. 21, no. 1, p. 140, 2019.

[145] M. N. Sarian, Q. U. Ahmed, S. Z. Mat So'ad et al., "Antioxidant and Antidiabetic effects of flavonoids: a structureactivity relationship based study," BioMed Research International, vol. 2017, Article ID 8386065, 14 pages, 2017.

[146] N. Guo, M. Zhu, X. Han, D. Sui, Y. Wang, and Q. Yang, “The metabolism of salidroside to its aglycone p-tyrosol in rats following the administration of salidroside," PLoS One, vol. 9, no. 8, Article ID e103648, 2014.

[147] W.-J. Zhang, S. Wang, C.-z. Kang et al., "Pharmacodynamic material basis of traditional Chinese medicine based on biomacromolecules: a review," Plant Methods, vol. 16, no. 1, p. 26, 2020.

[148] P. Zeng, Y. Zhang, C. Pan et al., "Advances in studying of the pharmacological activities and structure-activity relationships of natural C-glycosylflavonoids," Acta Pharmaceutica Sinica B, vol. 3, no. 3, pp. 154-162, 2013.

[149] X. Luo, N. Bao, L. Chen, and J. Sun, "Pharmacological activities and progress in structure modification of salidroside," Medicinal Chemistry, vol. 7, no. 3, pp. 813-823, 2017.

[150] L. Wu, P. Velander, D. Liu, and B. Xu, "Olive component oleuropein promotes $\beta$-cell insulin secretion and protects $\beta$-cells from amylin amyloid-induced cytotoxicity," Biochemistry, vol. 56, no. 38, pp. 5035-5039, 2017.

[151] J. Xu, Y.-F. Jia, S. Tapadar et al., "Inhibition of TBK1/IKKE promotes regeneration of pancreatic $\beta$-cells," Scientific Reports, vol. 8, no. 1, Article ID 15587, 2018.

[152] H. Duan, J. W. Lee, S. W. Moon et al., "Discovery, synthesis, and evaluation of 2,4-diaminoquinazolines as a novel class of pancreatic $\beta$-cell-protective agents against endoplasmic reticulum (ER) stress," Journal of Medicinal Chemistry, vol. 59, no. 17, pp. 7783-7800, 2016.

[153] P. Singh, V. K. Singh, V. K. Singh, and A. K. Singh, "Molecular docking analysis of candidate compounds derived from medicinal plants with type 2 diabetes mellitus targets," Bioinformation, vol. 15, no. 3, pp. 179-188, 2019.

[154] A. Natarajan, S. Sugumar, S. Bitragunta, and N. Balasubramanyan, "Molecular docking studies of (4Z, 12Z)-cyclopentadeca-4, 12-dienone from Grewia hirsuta with some targets related to type 2 diabetes," BMC Complementary and Alternative Medicine, vol. 15, no. 1, p. 73, 2015.

[155] Q. Wu and Y. Hu, "Systematic evaluation of the mechanisms of Mulberry leaf (Morus alba Linne) acting on diabetes based on network pharmacology and molecular docking," Combinatorial Chemistry \& High Throughput Screening, vol. 24, no. 5, pp. 668-682, 2020.

[156] H. Duan, Y. Li, D. Arora, D. Xu, H.-Y. Lim, and W. Wang, "Discovery of a benzamide derivative that protects pancreatic $\beta$-cells against endoplasmic reticulum stress," Journal of Medicinal Chemistry, vol. 60, no. 14, pp. 6191-6204, 2017.

[157] K. Kumar, P. Man-Un Ung, P. Wang et al., "Novel selective thiadiazine DYRK1A inhibitor lead scaffold with human pancreatic $\beta$-cell proliferation activity," European Journal of Medicinal Chemistry, vol. 157, pp. 1005-1016, 2018.

[158] K. Kumar, P. Wang, R. Sanchez, E. A. Swartz, A. F. Stewart, and R. J. DeVita, "Development of kinase-selective, harminebased DYRK1A inhibitors that induce pancreatic human $\beta$-cell proliferation," Journal of Medicinal Chemistry, vol. 61, no. 17, pp. 7687-7699, 2018.

[159] World Health Organization, WHO Traditional Medicine Strategy: 2014-2023, World Health Organization, Geneava, Switzerland, 2013.

[160] R. Chawla, P. Thakur, A. Chowdhry et al., "Evidence based herbal drug standardization approach in coping with challenges of holistic management of diabetes: a dreadful lifestyle disorder of 21st century," Journal of Diabetes \& Metabolic Disorders, vol. 12, no. 1, p. 35, 2013.

[161] D.-C. Hao, G.-B. Ge, P.-G. Xiao, P. Wang, and L. Yang, "Drug metabolism and pharmacokinetic diversity of ranunculaceae medicinal compounds," Current Drug Metabolism, vol. 16, no. 4, pp. 294-321, 2015.

[162] J. Yu, R. Zhang, T. Zhang et al., "Determination of toosendanin and trans-anethole in Fructus Meliae Toosendan and Fructus Foeniculi by HPLC-MS/MS and GC-MS/MS in 
rat plasma and their potential herb-herb interactions," Biomedical Chromatography: BMC, vol. 34, no. 7, Article ID e4837, 2020.

[163] C. T. Brewer and T. Chen, "Hepatotoxicity of herbal supplements mediated by modulation of cytochrome p450," International Journal of Molecular Sciences, vol. 18, no. 11, 2017.

[164] N. Li, Q. Xia, J. Ruan, P. P. Fu, and G. Lin, "Hepatotoxicity and tumorigenicity induced by metabolic activation of pyrrolizidine alkaloids in herbs," Current Drug Metabolism, vol. 12, no. 9, pp. 823-834, 2011.

[165] J. Lv, A. Sharma, T. Zhang, Y. Wu, and X. Ding, "Pharmacological review on asiatic acid and its derivatives: a potential compound," Slas Technology: Translating Life Sciences Innovation, vol. 23, no. 2, pp. 111-127, 2018.

[166] A. Aydın, G. Aktay, and E. Yesilada, "A guidance manual for the toxicity assessment of traditional herbal medicines," Natural Product Communications, vol. 11, no. 11, pp. 1763-1773, 2016.

[167] X. Yuan, R. L. Chapman, and Z. Wu, "Analytical methods for heavy metals in herbal medicines," Phytochemical Analysis, vol. 22, no. 3, pp. 189-198, 2011.

[168] R. Ganugula, M. Arora, P. Jaisamut et al., "Nano-curcumin safely prevents streptozotocin-induced inflammation and apoptosis in pancreatic beta cells for effective management of type 1 diabetes mellitus," British Journal of Pharmacology, vol. 174, no. 13, pp. 2074-2084, 2017. 